\title{
Verbal Noun and Inflected Verb
}

\section{Mhemed Abdulfetah (MEHWI) \& Aryan Sdiq AZIZ}

Received: Oct 08, 2017 Reviewed: Dec 15, 2017 Accepted: Dec 15, 2017

\begin{abstract}
Verbal noun is recorded in dictionary and its inflection process occurs in syntax. Producing inflected verb that has tense and person is found in syntax. Morphology is a system for creating new words for new things. Analyses have shown that internal structure of verbal nouns important inclitic division (subject and object) and inflectional pronouns in a complicated verb. The inflection is in syntax, in association with morphosyntax. So, inflection is morphosyntactic inside syntax. For past inflection, we take the tense base from the dictionary. While for present, we take the root then we bring tense and person. Dictionary, word creation morphology and syntax are interrelated. In this way, segmental changes are phonological and occur in the mind. Verb inflection categories are person, tense, aspect and mood. They are in complementary distribution in terms of: singular and plural, past and present, perfective and imperfective, indicative and uncertainty. Their structured, which are used, are:

1. Person: singular and plural

2. Tense: past /-a/, /yli-/, /wlu-/, /d-/, /t-/ .and present /de-/.

3. Aspect: each of the linguists Mhamed Mehwi, Wrya Omar Amin and Mahmud Fathulla divided aspect into perfective, imperfective and progressive. However, through analysis and discussion of examples, it has been obvious that aspect is of two types in Kurdish language.The researcher follows the latter conclusion:

a. Perfective

b. Imperfective (Continuous), Progressive (close) and far.
\end{abstract}

Tense and aspect, which are the verbal inflectional categories, are parts of tense. Tense determines past and present, but aspect determines its perfectness and imperfectness.

4. Mood: Indicativelinformative

uncertainty (structural, subjunctive, imperative and request)

Key words: Verbal Noun, Inflected Verb, Kurdish Linguistics, Kurdish

\section{Recommended citation:}

Mehwi, M.A. \& Aziz, A.S. (2018). Verbal Noun and Inflected Verb. International Journal of Kurdish Studies 4 (1), $1-27$, DOI:

\footnotetext{
${ }^{1}$ Prof. Dr., Department of Kurdish Language, College of Language , Sulaimani University, Sulaimani, Kurdistan Region - Iraq

2 - Assistant, Department of Kurdish Language, College of Language ,specialty: PH.D Language Sulaimani University, Sulaimani, Kurdistan Region - Iraq
} 


\title{
ناوى كرداريى و كردارى شكاوه
}

\author{
بهشى يaكمر \\ فهرهمنك
}

1/1/) يوّله رمكهزه فهرهمنكيهكان

/ / - (1)ناوى كرداريى وهى يؤله رهكَزيّيى فهرههنكيى (دهروازهى زانياريى)

/ / ( ) كردارى لاواز و كوّيولا

(T/) دروستهى ناوهوهى ناوى كرداريى

بهـ دوهم

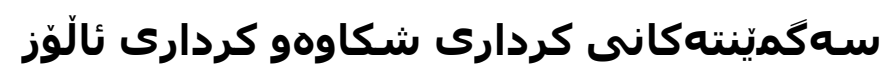

ז/ ( - ) موّرفيم و ئهلهمورفهكانى دابوردوو

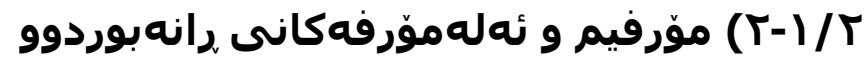

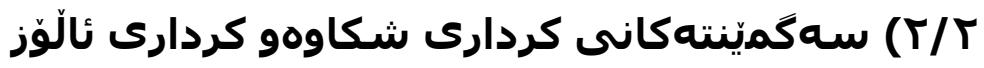

بهشى سديّهم

شكاندنهوهى تافى رابوردوو و رانهبوردوو

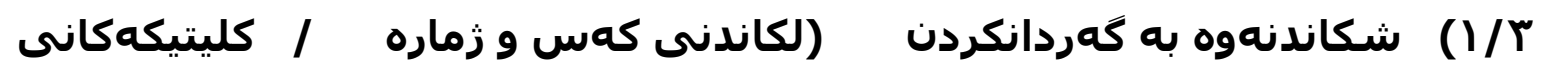

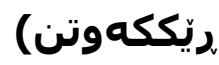

(T/Y) شكاندنهوه به كَهردانكردن و لكاندنى كهسى ديّككهوتن

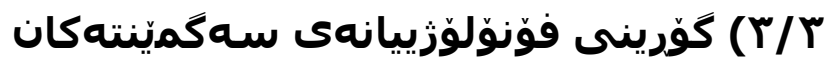

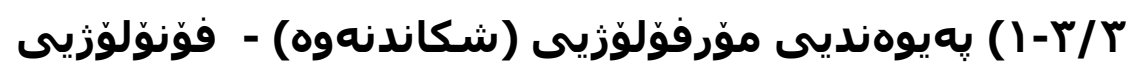

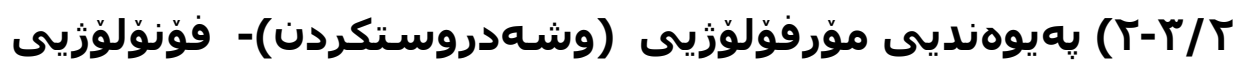
بهشى :جوارهمر

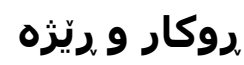

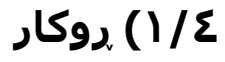




\section{ناوى كرداريى و كردارى شكاوه}

رِيْشَكيى

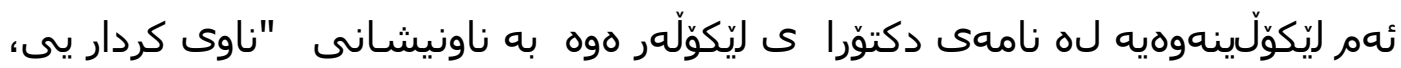

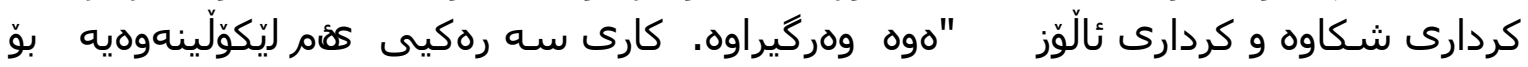

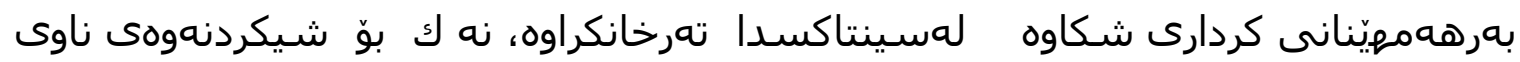

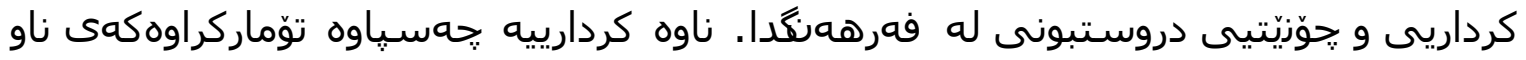

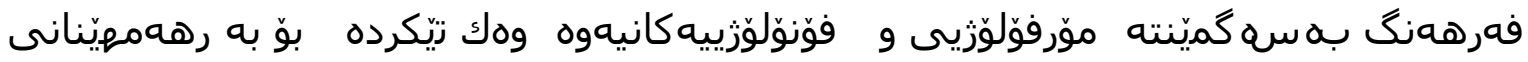

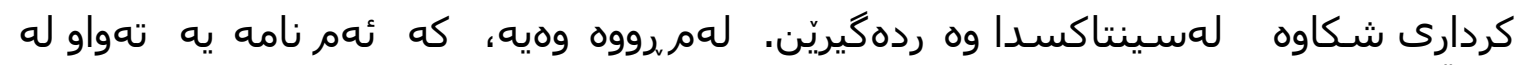

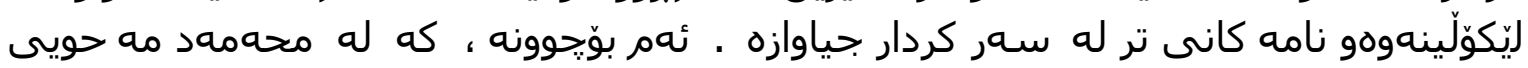

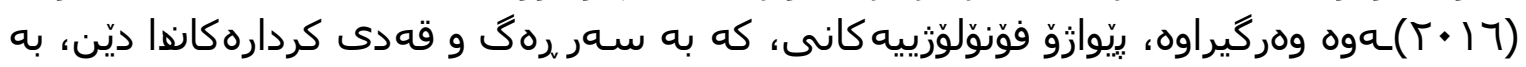

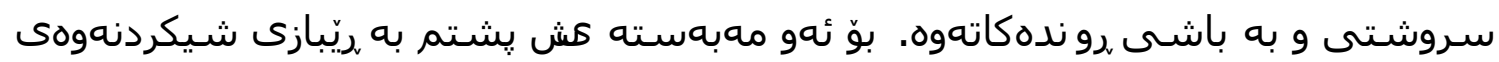

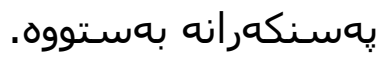

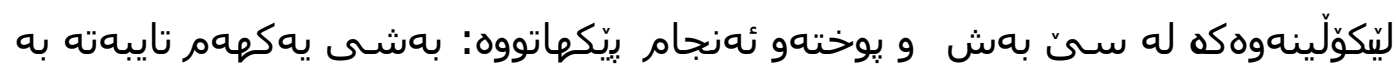

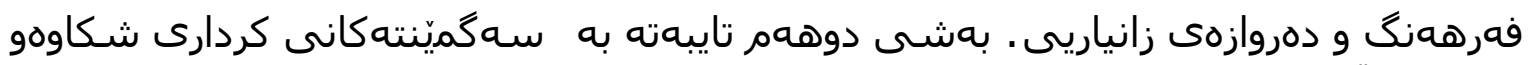

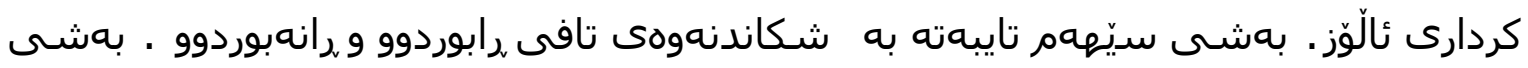

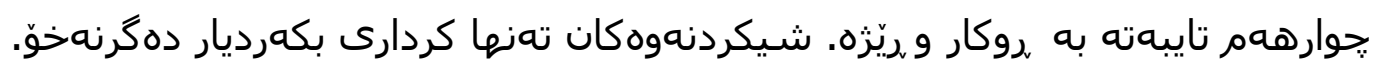

$$
\text { فهشى يهكبم }
$$

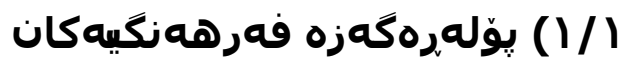

زانيارييه سينتاكسـيى و واتاييهكاه وشـكان له فهرههنكدا توماركراون، ئوهكش

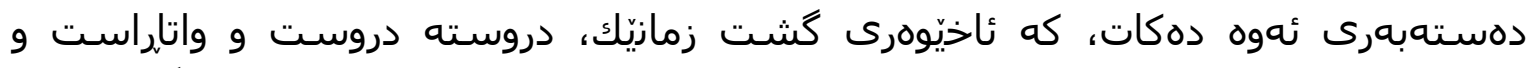

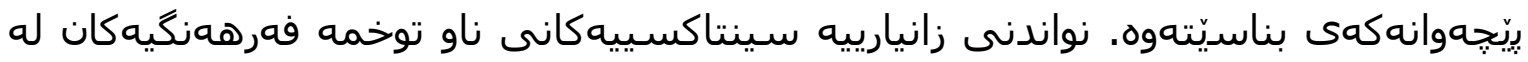

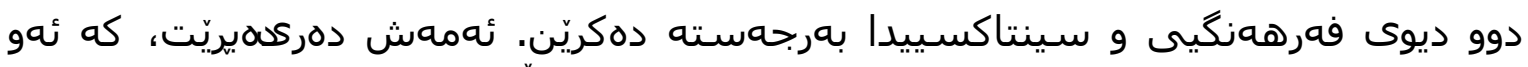

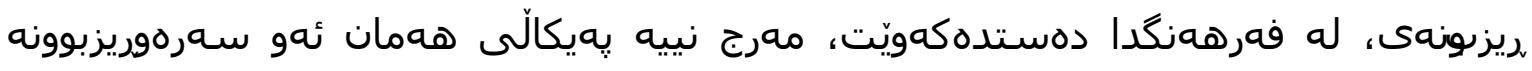

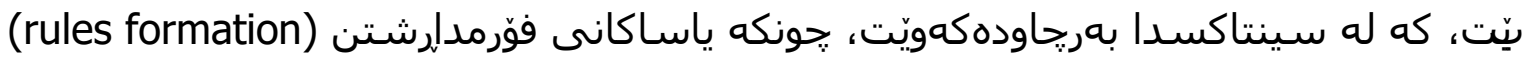

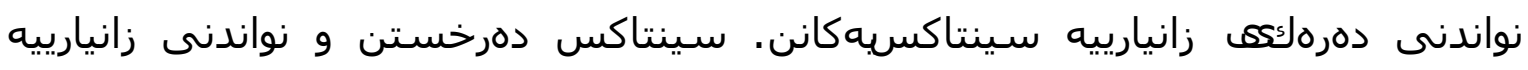




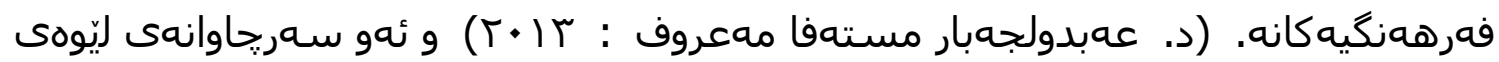
وهركيراون.)

\section{| / - (1)ناوى كرداريى وهى بوّله رهكَزيّى فهرههنكيى (دهروازهى زانياريى)}

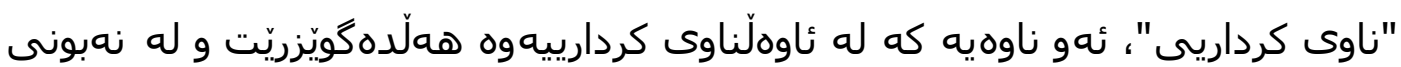

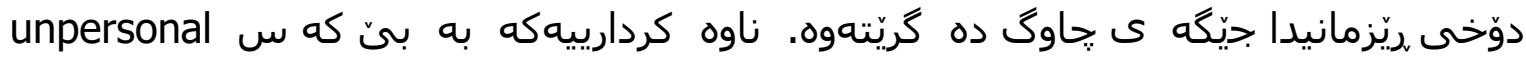

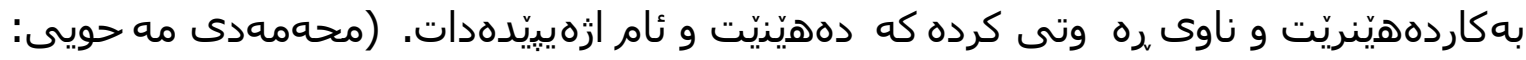

(256:2009

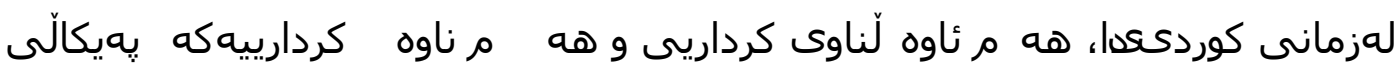

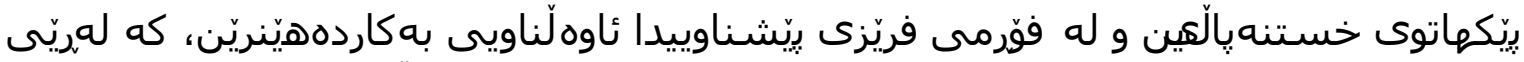

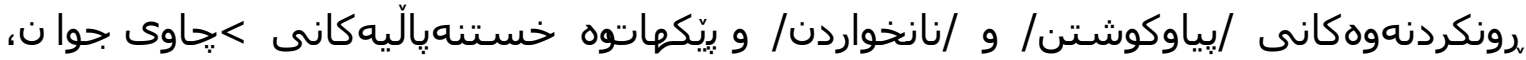

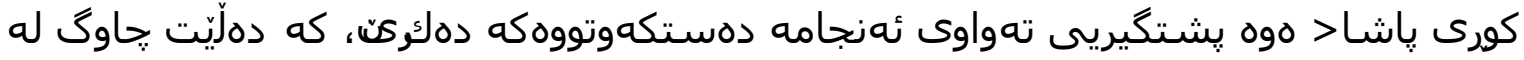

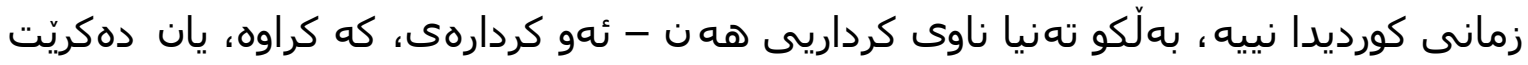

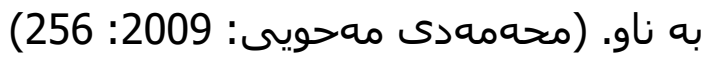

ناوى كرداريى له فهرههنكدا توّماركراوهو يِينوازَوّى شـكاندنهوهى له سينتاكسـا

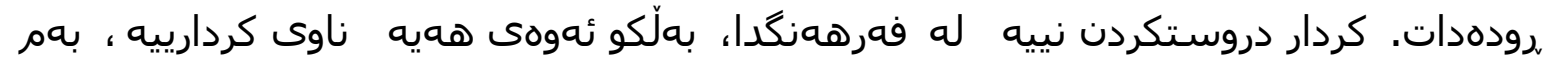

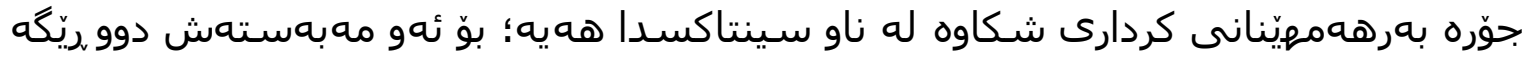

هميه:

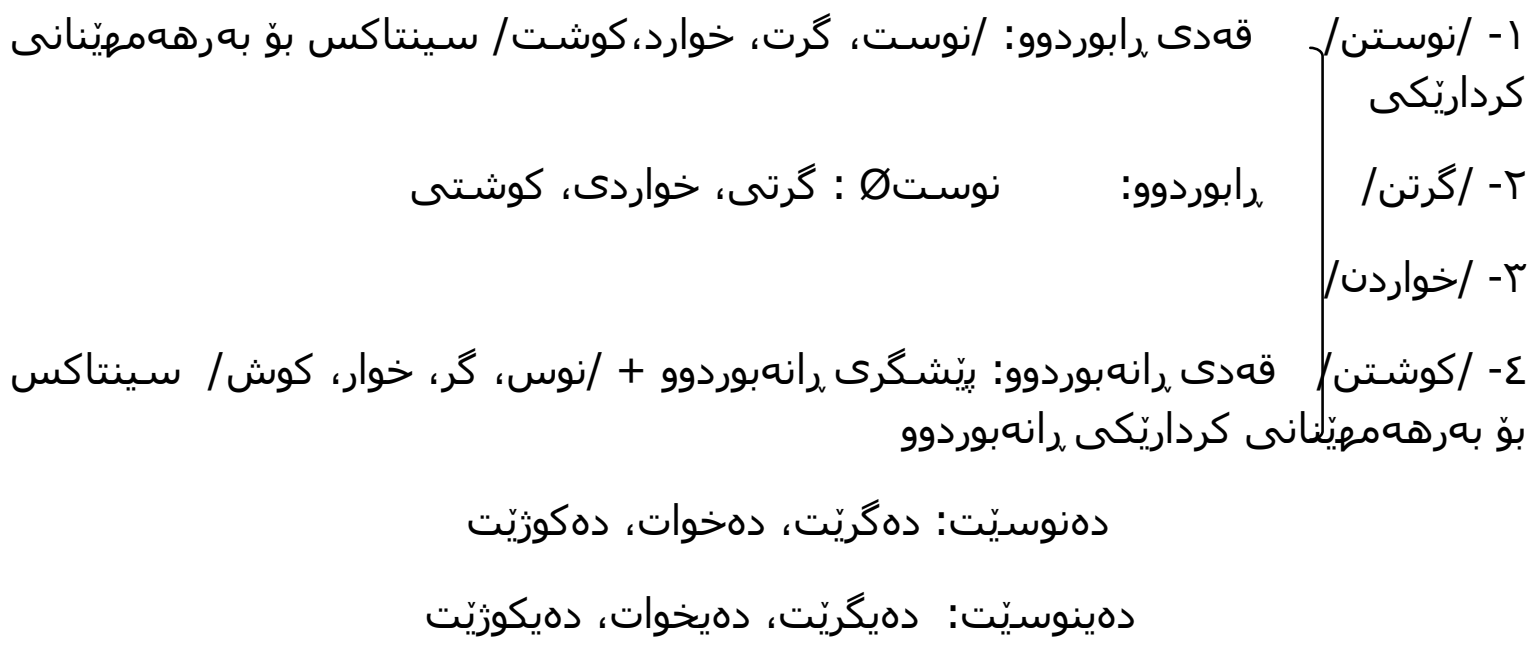

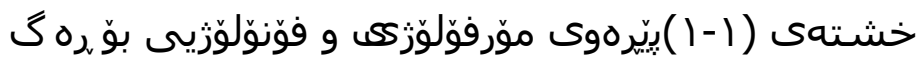

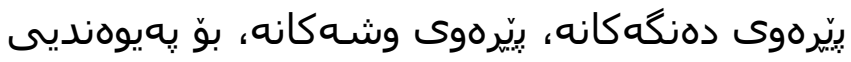

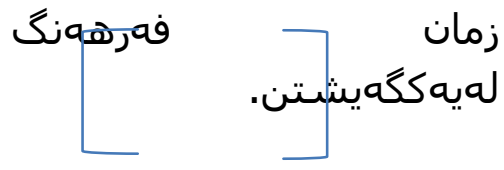

International Journal of Kurdish Studies Vol.4/1 ( January 2018) 


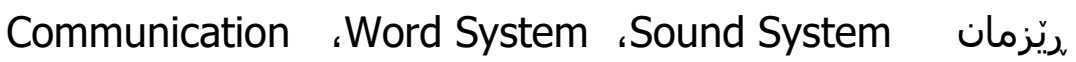

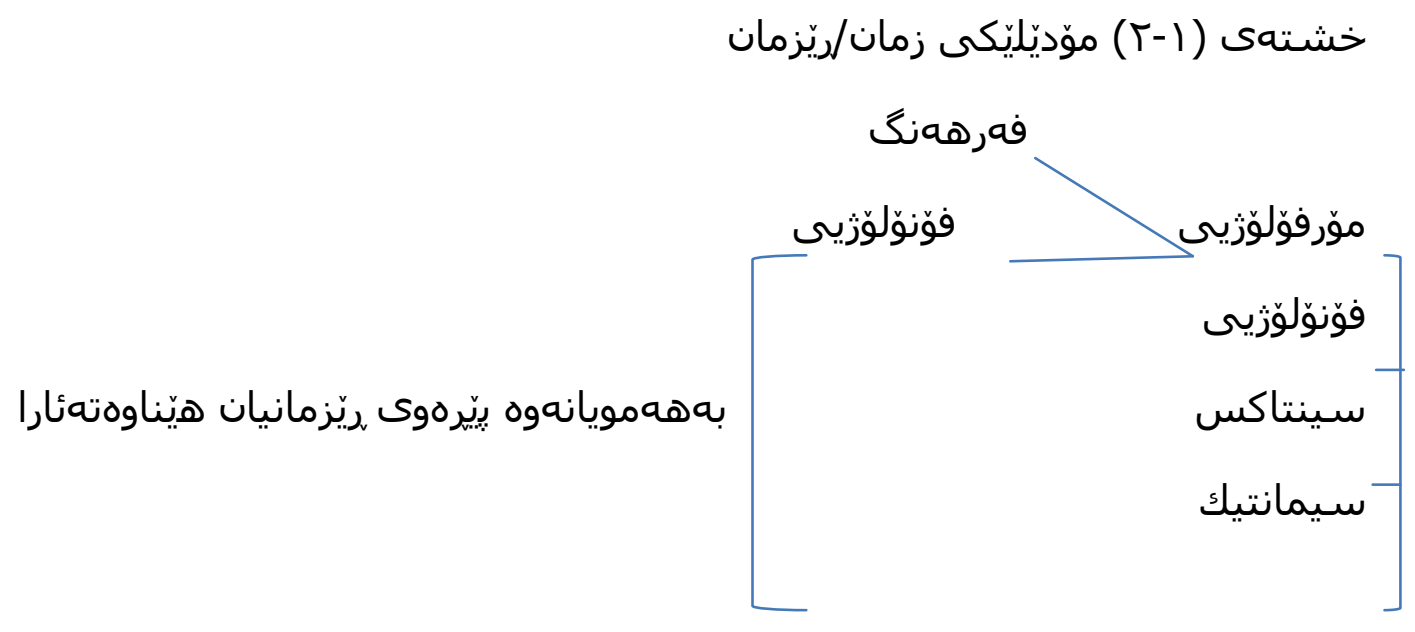

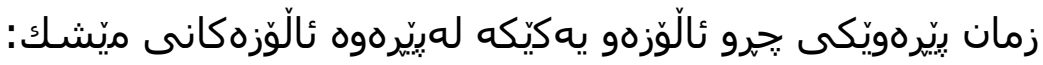

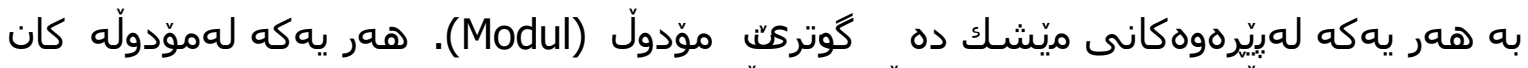

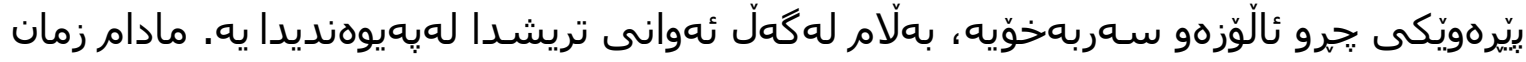

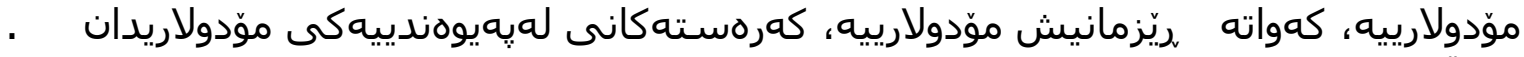

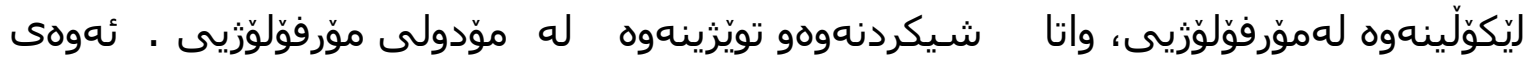

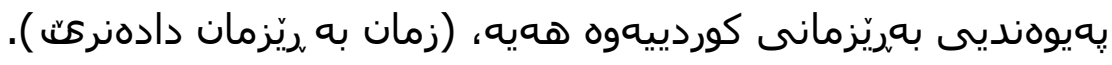

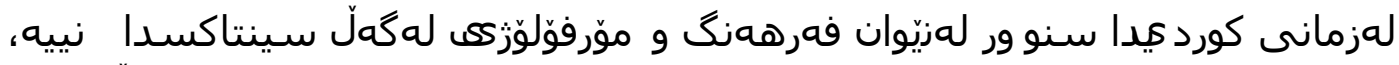

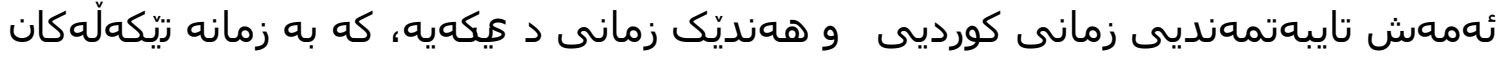

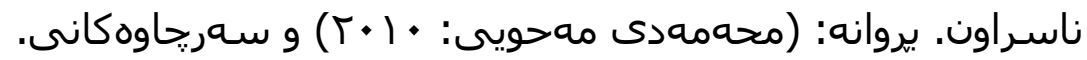




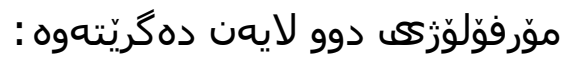
يهكهذمر: وشـدروستكردن (Word Bulding)، بوّ واتاى نوىّ. دووه هم: شكاندنهوه (Word Inflection- Word Formating). بوّ بهرههمعِينانى وشـهو بِيككباتوى سـومن شينتاكسيى يهك كهم : موّرفوّلوّرَيى وشـدروستكردن (Word Bulding):

$$
\begin{aligned}
& \text { بوّ واتاى نويّيهج ليَكدراو: /سـهركگرتن/ }
\end{aligned}
$$

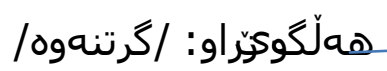

$$
\begin{aligned}
& \text { داريّرَاو: /لِّوهركرتن/ } \\
& \text { وشـهى فريزى (Frasal Word): /دهسبـهسـرداگرتن/ }
\end{aligned}
$$

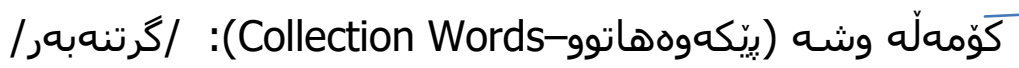

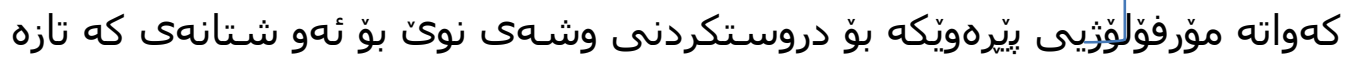
ديّنهئاراوه.

دوه هم : موّرفوّلوَزيى شكاندنهوه (Word Inflection- Word Formating):

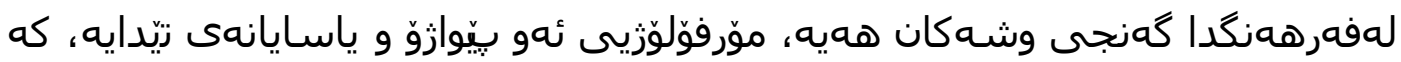

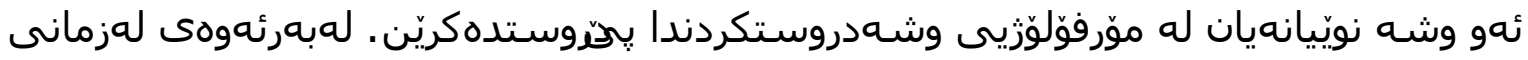

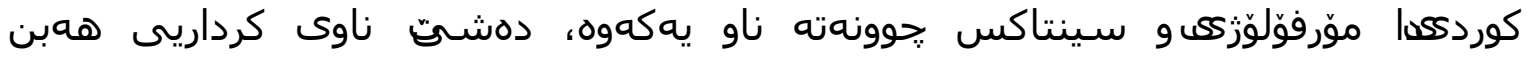

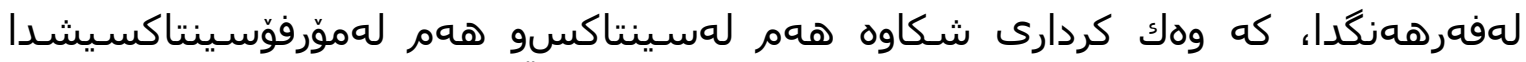

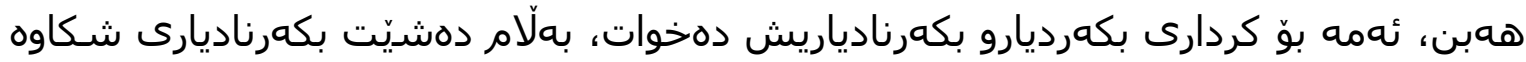

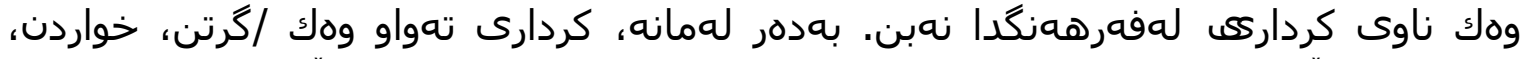

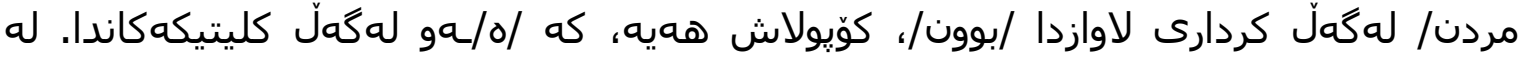

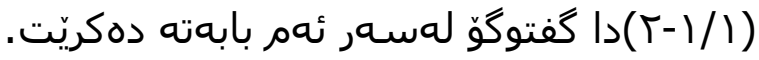

\section{/ / (T) كردارى لاواز و كوَّبولا}

0- /سـوزبوون/ يوون كردارى لاواز و كوّيولا

0-|) /جيمهنهكه سـوزبوو/. (كردهيى) يِقـتر سهوزنهبوو، يَّستا سـوزه.

$$
\text { 0-ب) / إحيمهنهكه سهوز بو/. (حالّتيى) }
$$

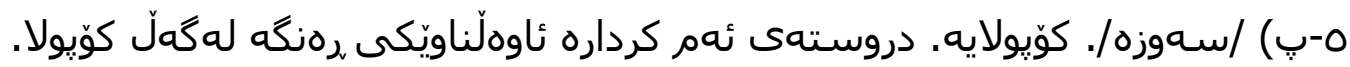

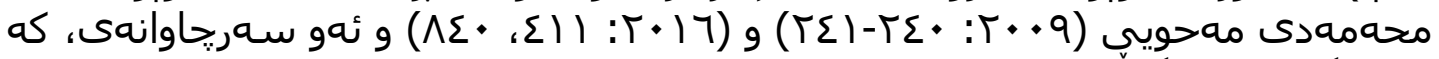

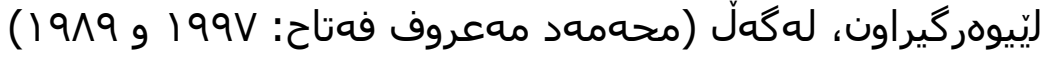


(وريا عومهر ئهمين) تهنها /- ه، ب، بوو/ ى به كوّيولا داناوه. (109-97 : 2011)

\section{(T/) دروستهى ناوهومى ناوى كرداريى}

ناوى كرداريى بريتييه له (رذگى كردارى تافى ،رابوردوو + تافهكى)

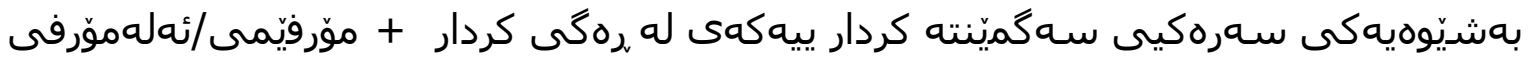

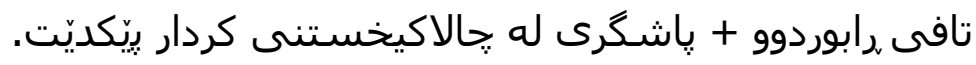

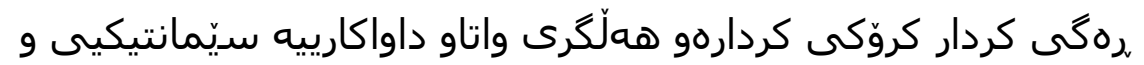

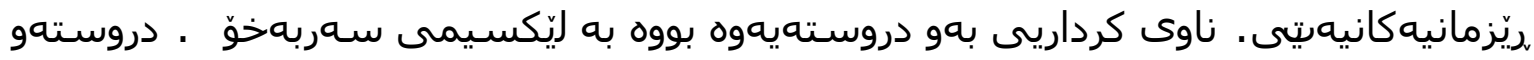

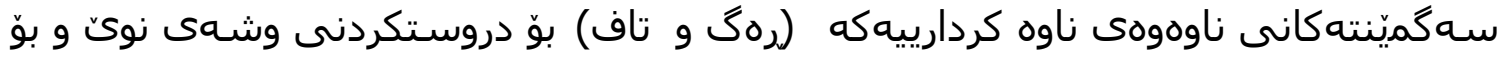

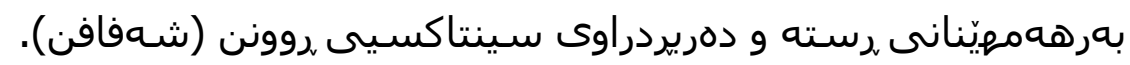

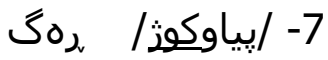

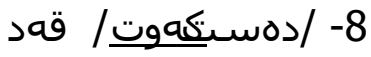

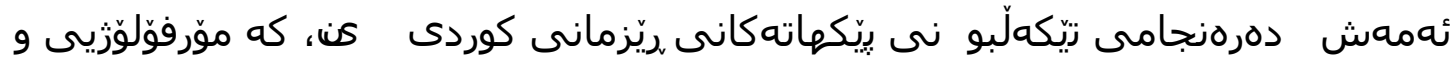
سـينتاكسـن

شـيكردنهوهكان دهريدهخهن، كه دروستهى ناوه وهى ناوه كردارييهكان بوّ دابهشبونى كليتيك

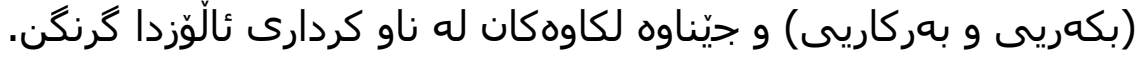

$$
\begin{aligned}
& \text { 9- } \\
& \text { 10- /نوسـتـ/ } \\
& 1 \text { ו- / / }
\end{aligned}
$$

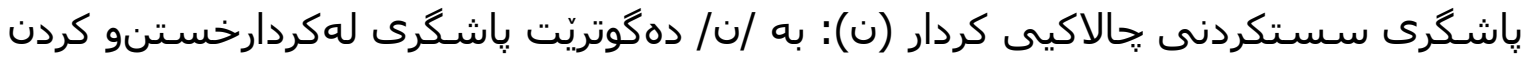
بaناو.

\section{(1) دروستهى ناوى كردارك ساده :}

قدى تافيى (رهگ + تاف) + /- ن/ ى بهناوكردن و لهكارخستن

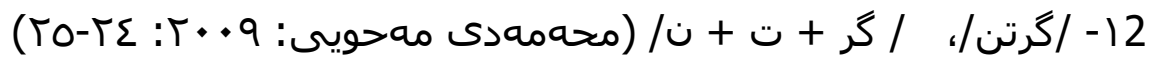
ب) دروستهى ناوى كرداركى ليّكدراو: وشـه + ناوى كرداريى ساده 31- /سهرهگرتن/، /سهره + گرتن/، /سهره + گر + ت + ن/ 
ب) دروستهى ناوى كرداركى دارِيرزراو : موّرفيّمى وشهدإريّز (يان زياتر)+ ناوى كرداريى

$$
\begin{aligned}
& \text { 4ا-|) /ليّوهركرتن/، /لني + وهر + كرتن/ }
\end{aligned}
$$

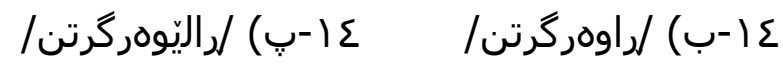

ت- دروستهى ناوى كرداركى هملّكَويزراو: ناوى كرداريى + بِاشكر

$$
5
$$

ح- دروستهى ناوى كرداركى فريّزيى: ئهم دروستهيه له دروستهى فريزّهوه نزيكه.

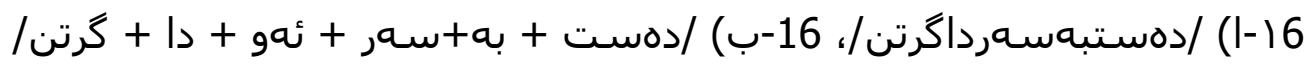
16-ب) /دهستى بهسهر ئهودا گرت./

ج- كوّملاله وشه :(بيّكهوههاتوو-Collection Words): ناوى لكرداريى+مورّفيّمى خستنهسهر + ( +

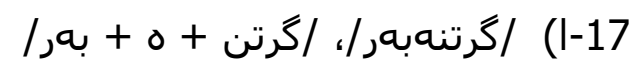

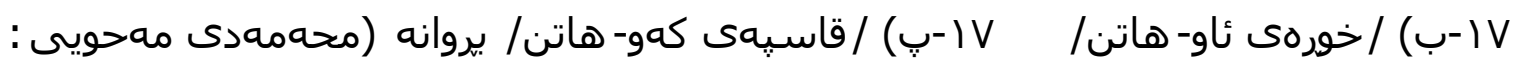

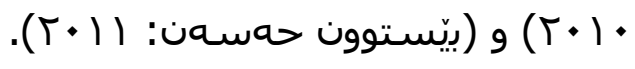

\section{بهش دوهםم}

\section{سهَمْينتهكانى كردارى شكاوهو كردارى نالِوَز}

\section{ז/ / - ) موّرفيم و ئهلهمورففكانى تافى رابوردووى كردار}

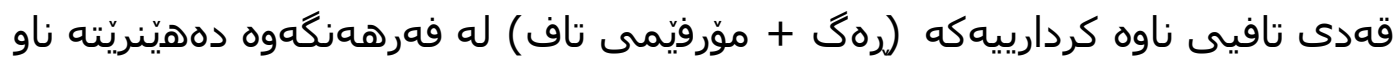

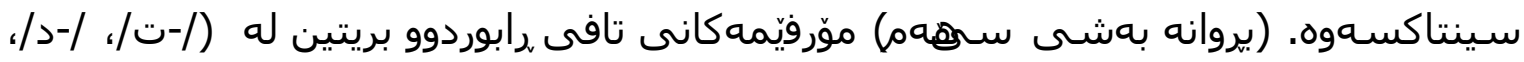

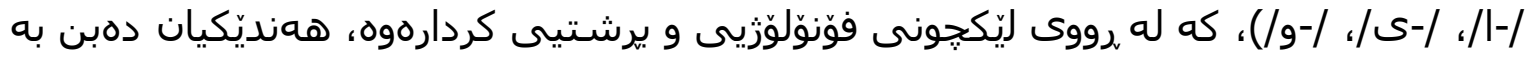

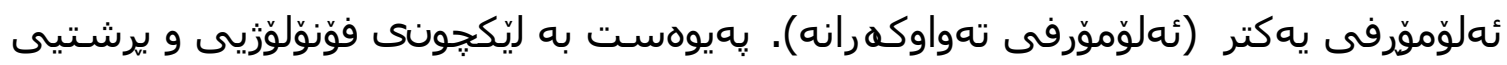

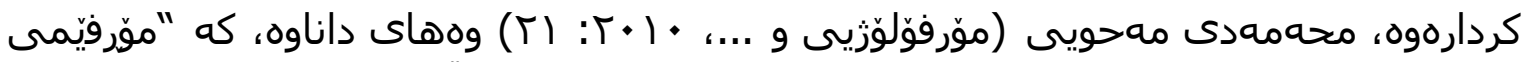

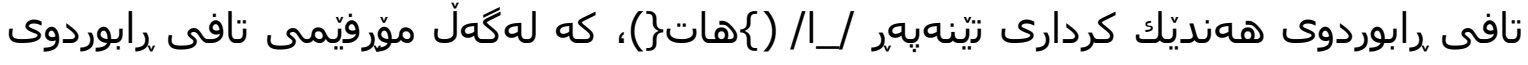




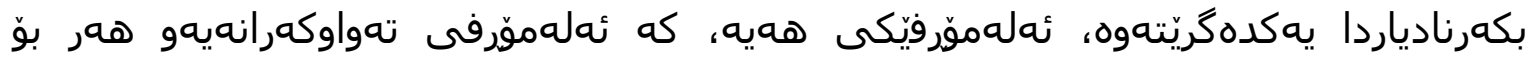

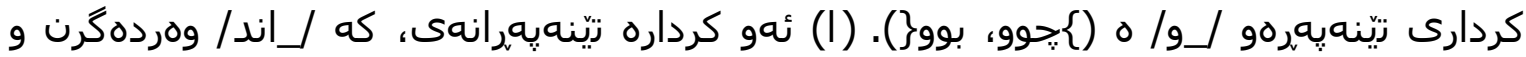

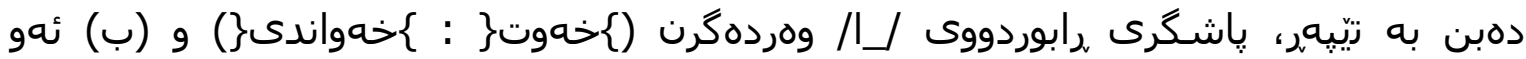

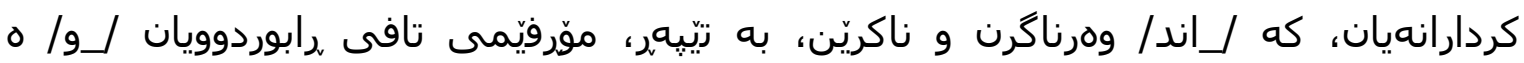

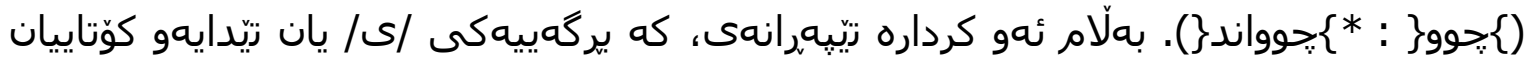

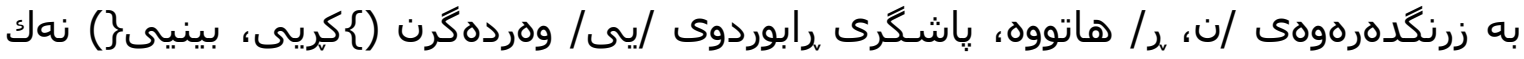

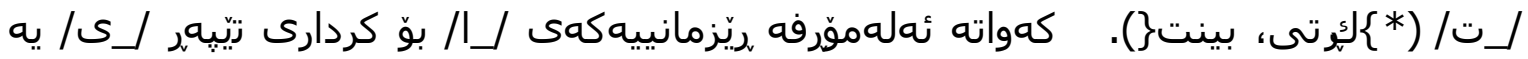

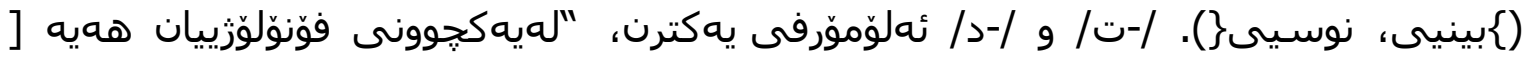
+کييراو، +يوكيى، +_لدهنكدار ]

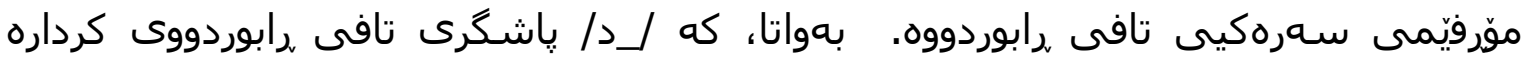

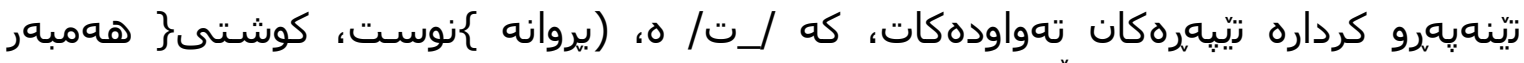

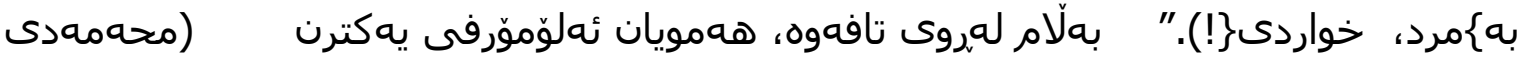

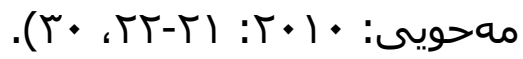

\section{T/ ا-T) موّرفيم و ئهلهمورفى تافى رانهبوردووى كردار}

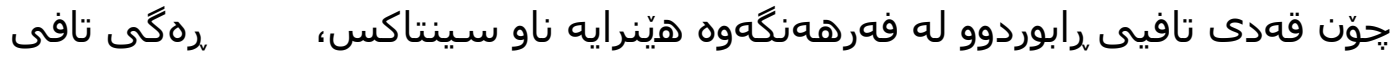

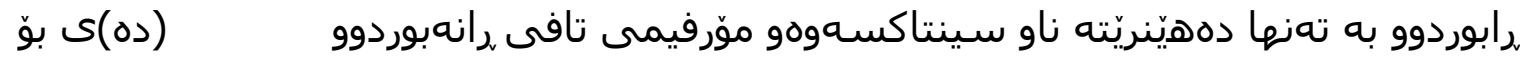

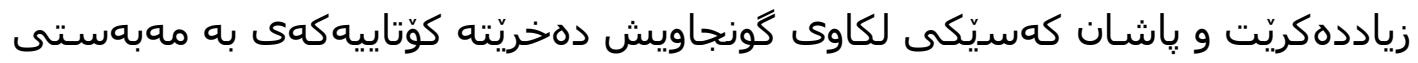

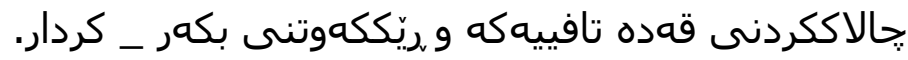

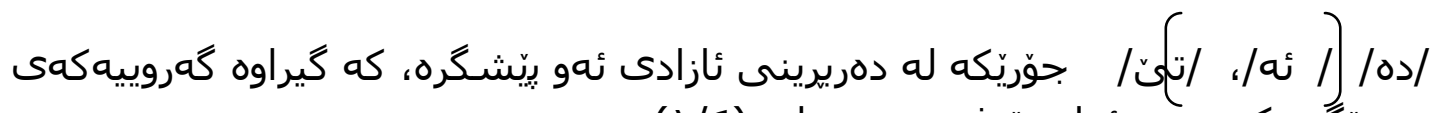

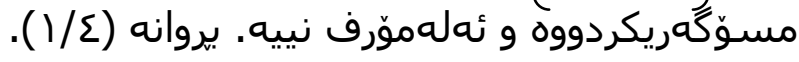

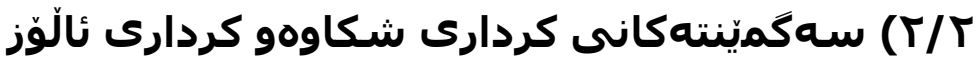 آ/ (1) ئهبوبهكر عومهر قادر}

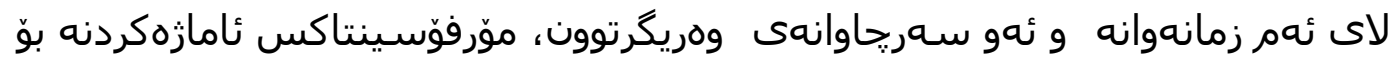

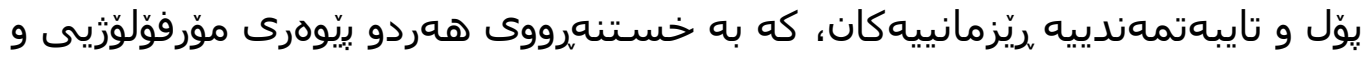

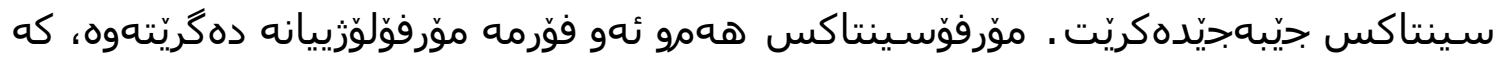

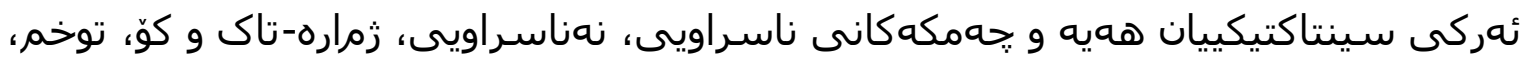

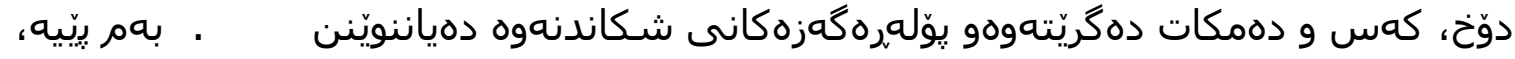

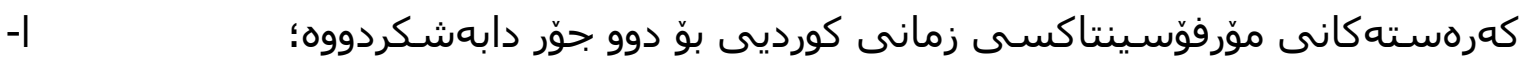

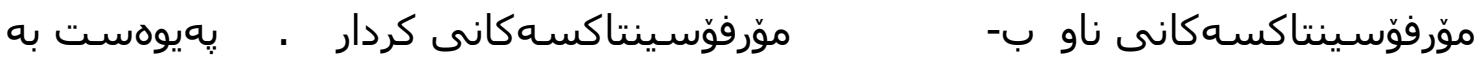




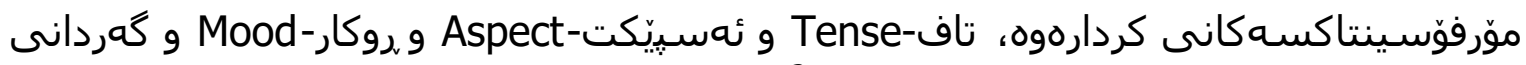
كردار-S Conjugations

(1-)

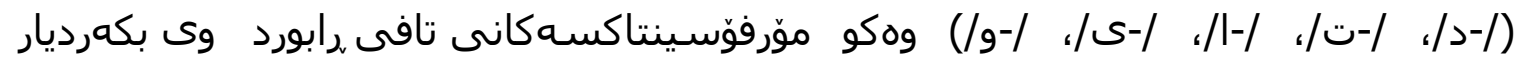
دياريكردووه.

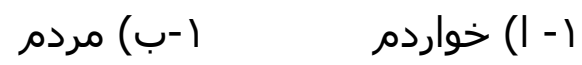

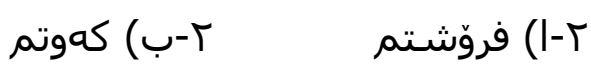
r (I- ) كريم (ب-0) :جووم موم ( $1-0$

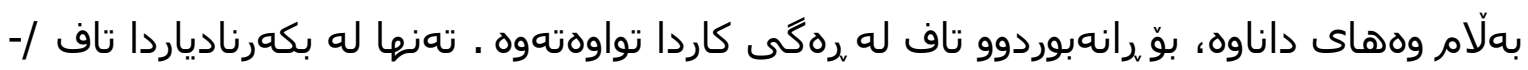

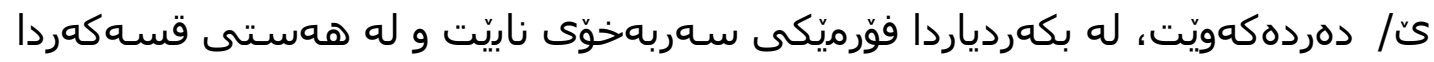
تواوهتوه.

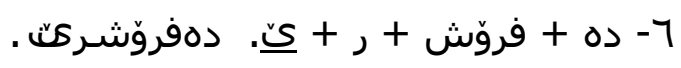

每

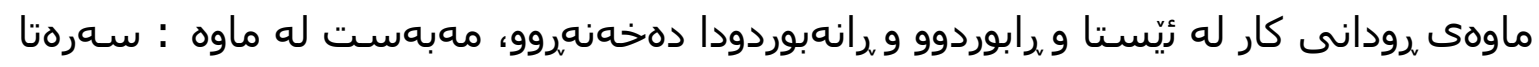

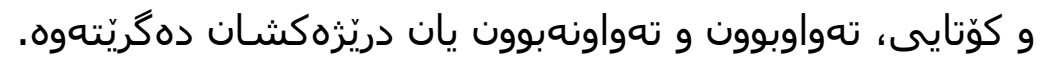
ليَكوّلّهر ئهم روكارانهى دهستنيشانكردوون [ده، ووه/وه، ه، موه/وه]

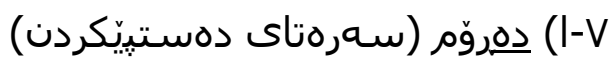

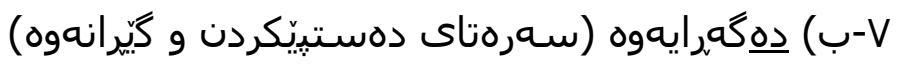

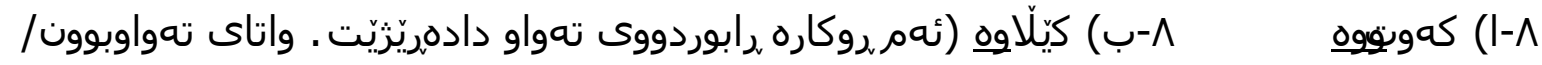

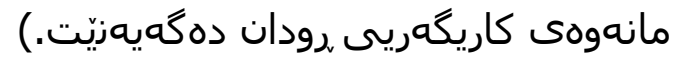

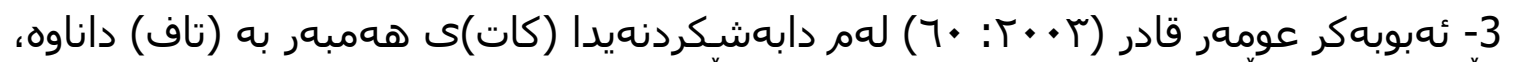

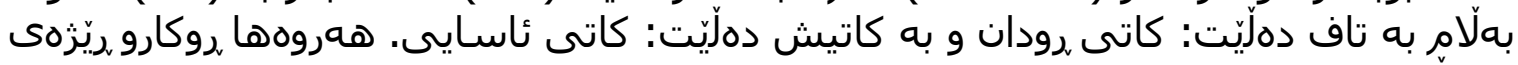

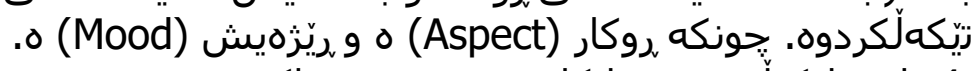

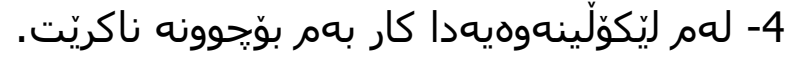

International Journal of Kurdish Studies Vol.4/1 ( January 2018 ) 


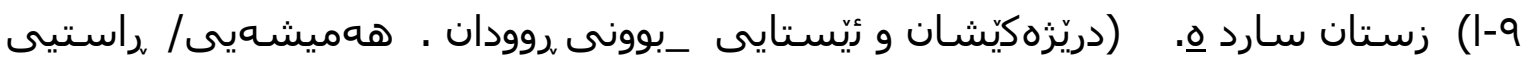
بنى_كات) 9-ب) هموا ئهمرو سارده. (ماوه سنوردار) • (-I) هايوومهنوهِ (دهمكاتى ريّستايى كار، دلّنيايى_بهخشيين به رودان يان تهواوبونيى). • (ب) ديّمهوه (ناينده)

\section{ديّز}

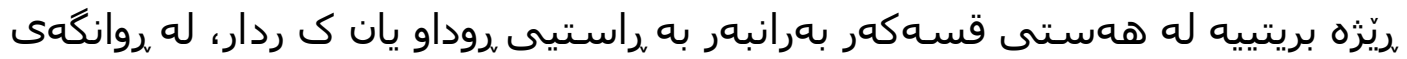

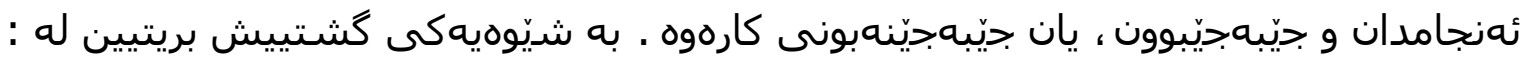

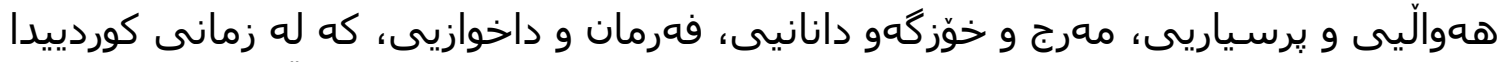

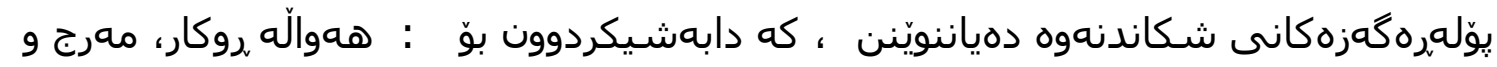

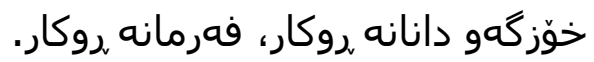

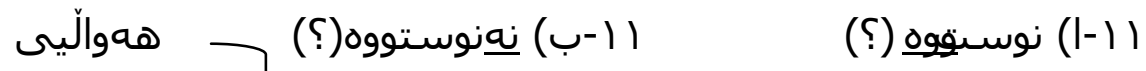

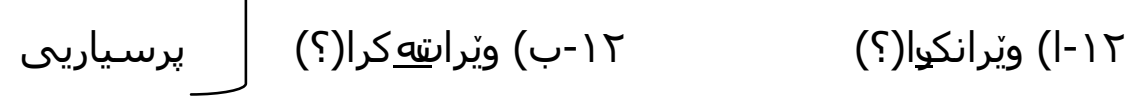

$$
\begin{aligned}
& \text { rا -|) ئه گهر نوسرايِت }
\end{aligned}
$$

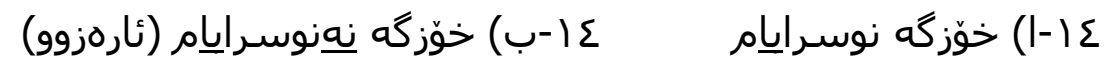

$$
\begin{aligned}
& 0 \\
& \text { 17 -I) ينوسه / يينوسه }
\end{aligned}
$$

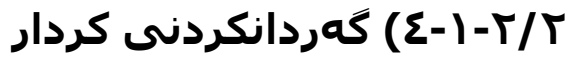

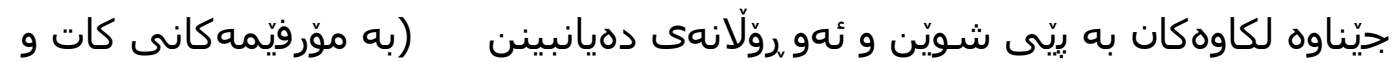

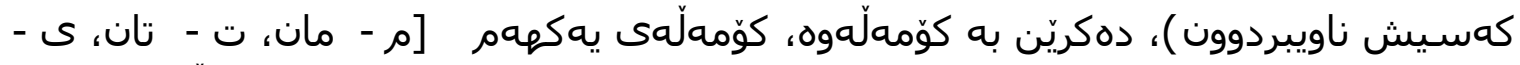

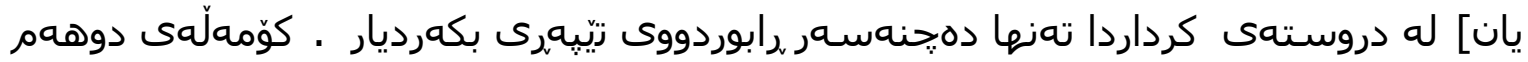

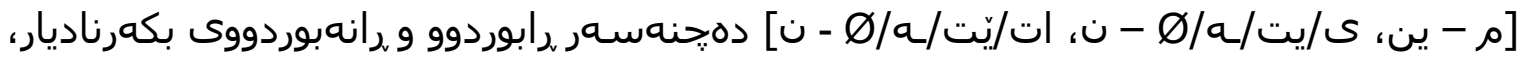

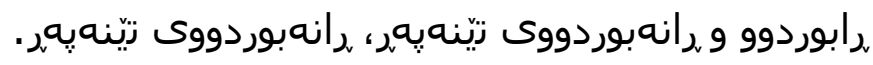

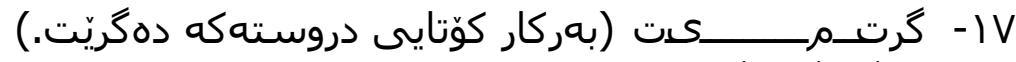

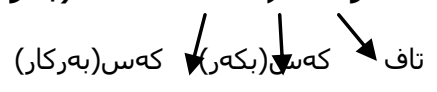

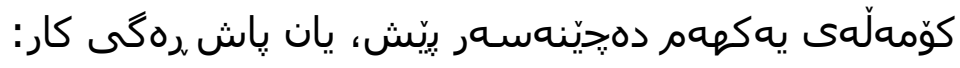



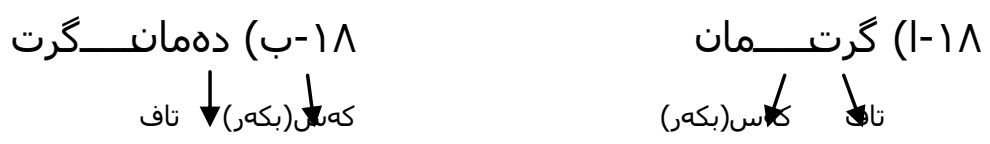

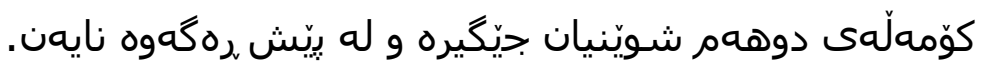

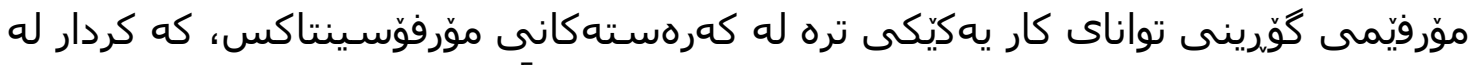

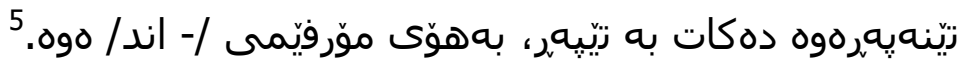

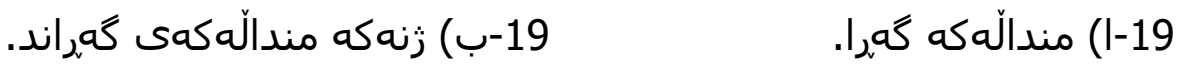

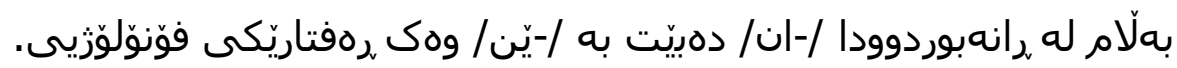
• •

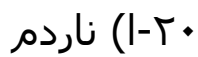

لاوازكردنى تواناى كاريش به كهرهستهى موّرفوّسينتاكس و به هوّى موّرفيّمى /-ر/ دوه له

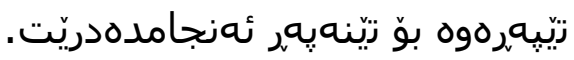

$$
\text { (ب) دزمكه كيرا. }
$$

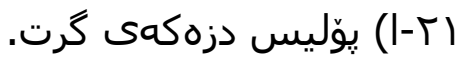

T آب) نهمام دهزيّزيّيت (ئهبوبهكر عومهر قادر

放

$(\Lambda T-T \Lambda: T \cdot \cdot r$

كورتهويوخته

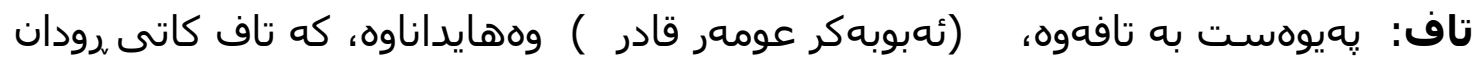

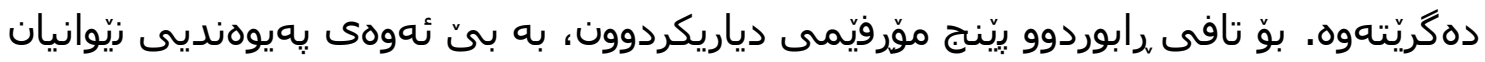

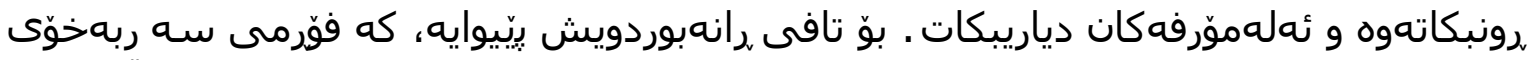

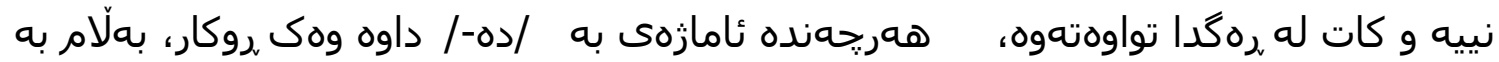

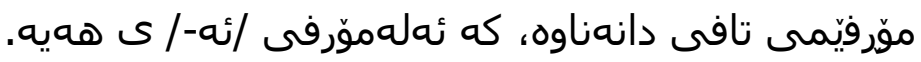

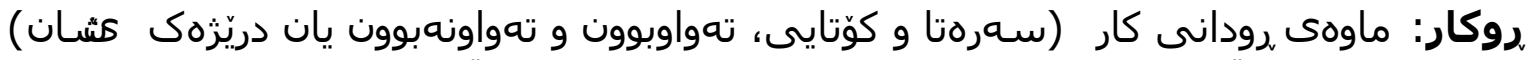

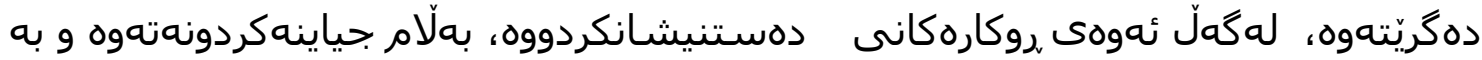

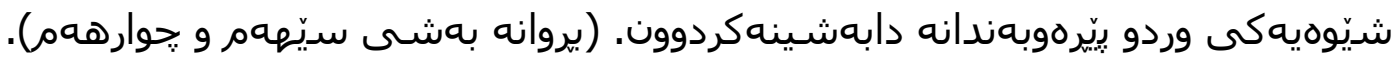

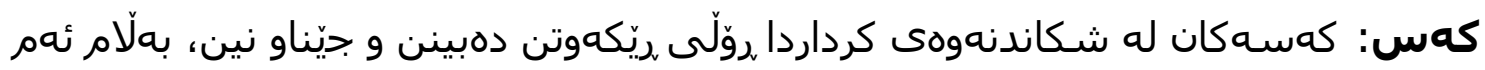

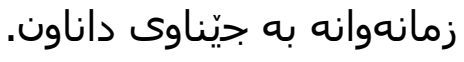

5- لههمان لايهرهدا ئهبوبهكر عومهر قادر دهلّيّت به هوّى موّرفيّمى /-ان/ موهيه و كارييِيكردووه.

International Journal of Kurdish Studies Vol.4/1 ( January 2018 ) 


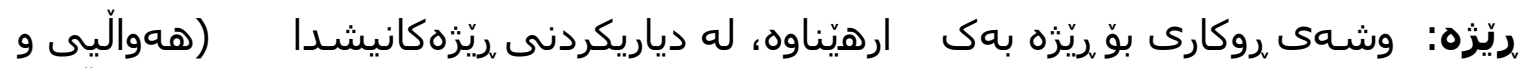

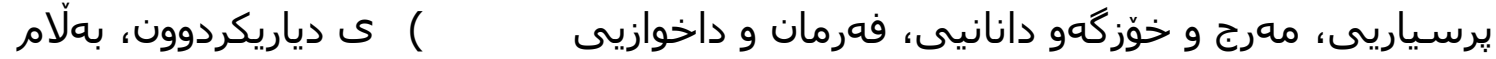

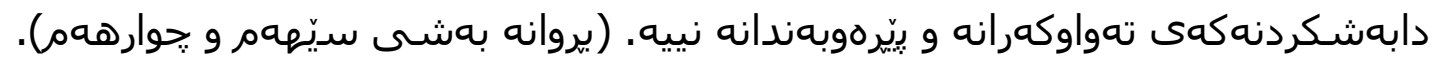

T/Y-T) وريا عومهر ئهميين

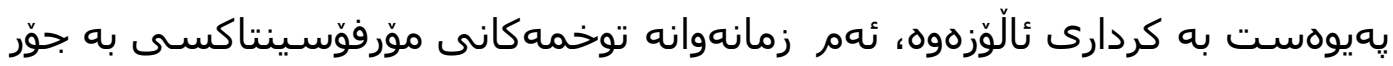

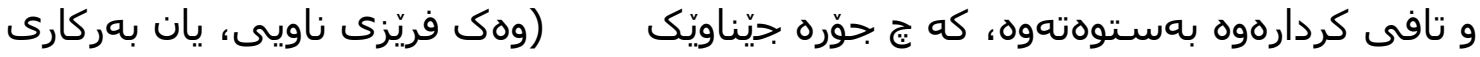

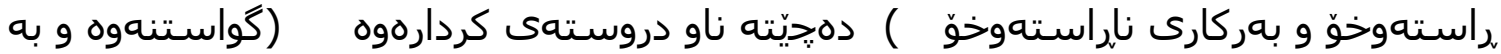

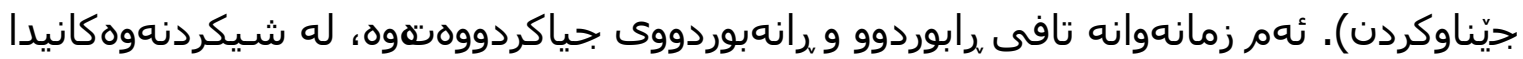

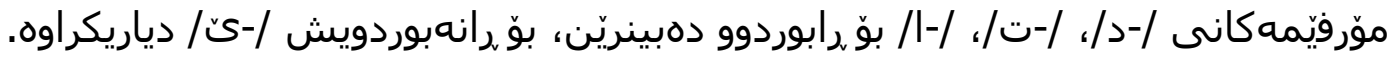

$$
\begin{aligned}
& \text { "ז- /خواردم| /-د/ } \\
& \text { عץ- /هاتم/ /-ت/ } \\
& \text { Oז- /كوثرا/ /- } \\
& \text { דץ- /ئهوترى/ /-؟ن/ }
\end{aligned}
$$

سـن كوّملَّه جِيناوى جحياواز ى

\begin{tabular}{|c|c|c|}
\hline كوَمهلّى سيّهِمر & كوّمهلّى دوهaم & كوّمهلّهى يهكهمر \\
\hline - & - & - \\
\hline - & - & - ت \\
\hline - |(ت)، كّ(ت) & $\varnothing-$ & s - \\
\hline - ين & - ين & - مان \\
\hline - ن & - ن & - يان \\
\hline
\end{tabular}

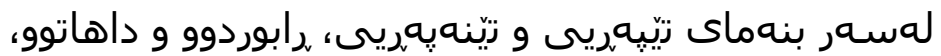

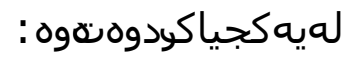

خشتهى (1 -ع) جيناوه لكاوهكان (له جيّناو دهدويّت، نهى كهسى لكاوى ريّكهوتن.) 


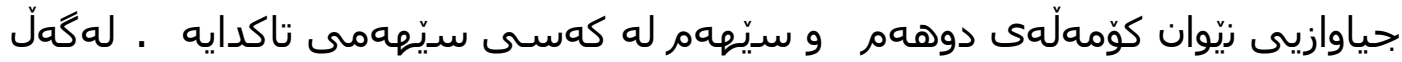

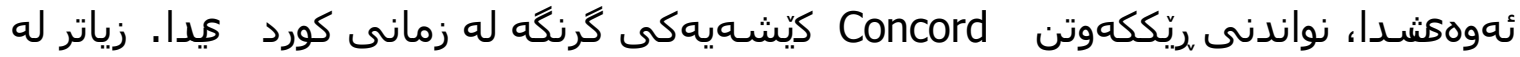

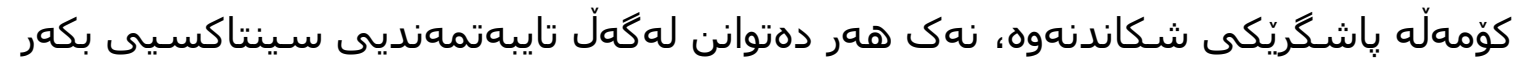

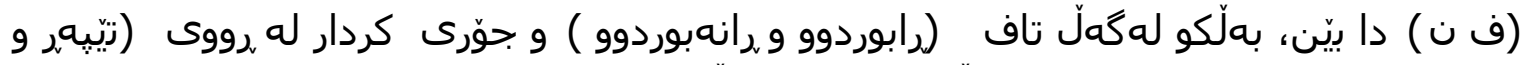

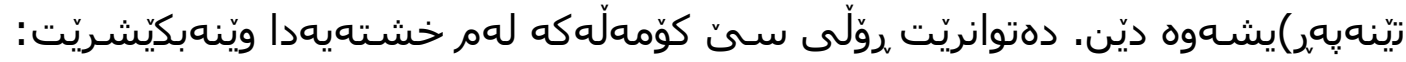

$$
\text { خشتهى زماره (1) (o- (o) }
$$

\begin{tabular}{|c|c|c|}
\hline & Transitive & Intransitive \\
\hline Past & 1 & 2 \\
\hline Present & 3 & 3 \\
\hline
\end{tabular}

كردار لهَّلّ بكهر (ف ن) دا له روووى زماره (تاك و كوّ) و كهس (يهكبهم و دوههم

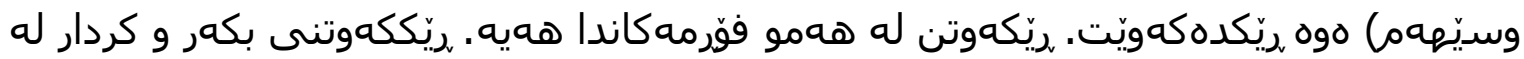

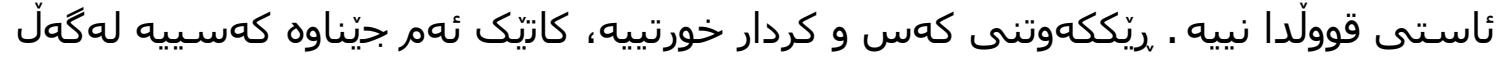

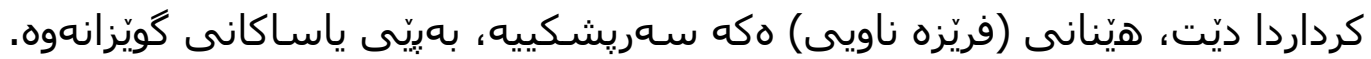

$$
\begin{aligned}
& \text { TV } \\
& \text { من (I-TV }
\end{aligned}
$$

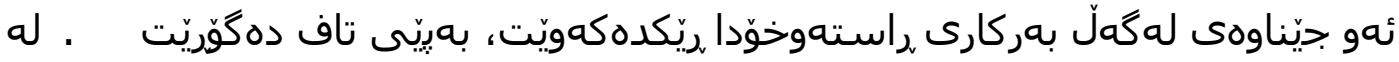

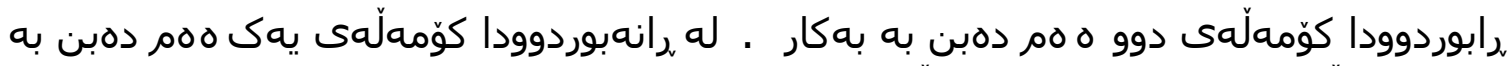

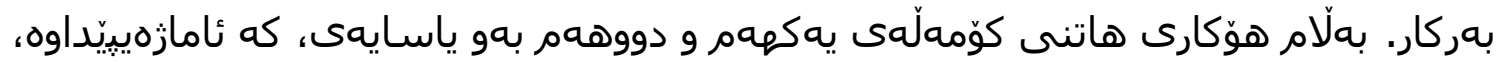

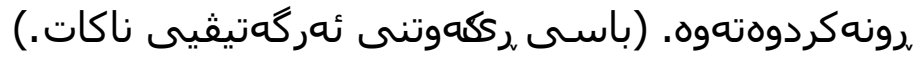

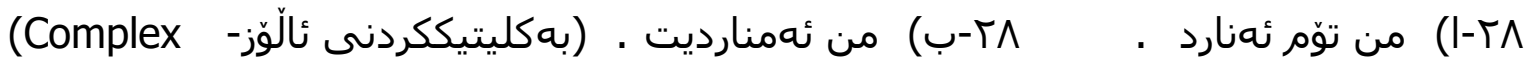
Cliticization

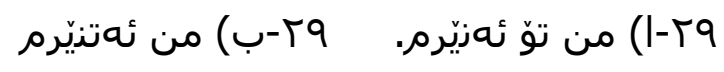

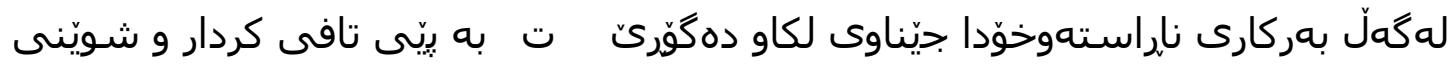
جيناوهكه:

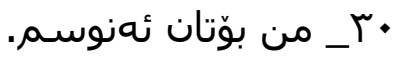
آr_ توّو بوّمانت نوسى.

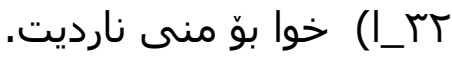
كا_ب) خوا توّى بوّ ناردم.

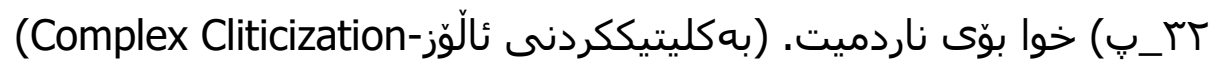
International Journal of Kurdish Studies Vol.4/1 ( January 2018 ) 


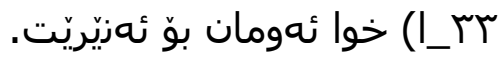

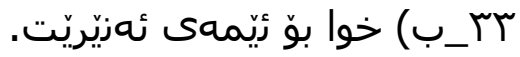

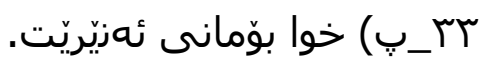

دوكار: له زمانى كوردكها سـن جوّر روكار سهلميّنراون: تهواوبوو، تهواونهبوو، تهواو.

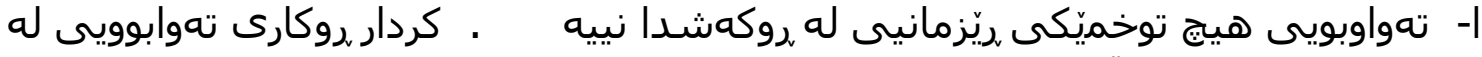

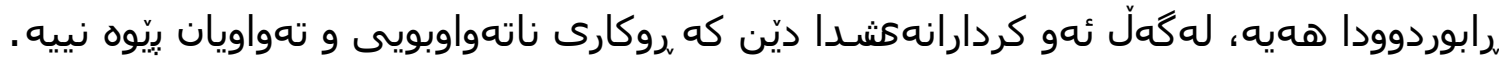

I ate $\quad>_{\rho}->$ د $>-r \Sigma$

I past eat

ب- فوّرم و بيِشكرى /ئه_/ بوّ تهواونهبويى دهيِيت . له زمانى كوردىكدا تهواونهبويى له رابوردوو و رانهبوردووكثـدا دهبينريّت.

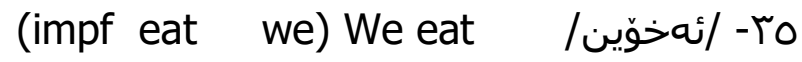
(impf sleep past we) we were sleeping / بأهنوستين/

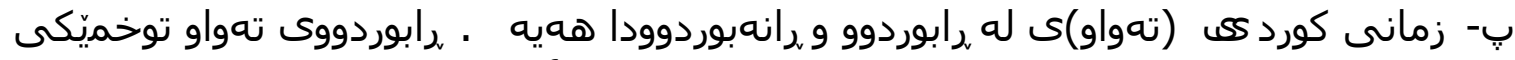

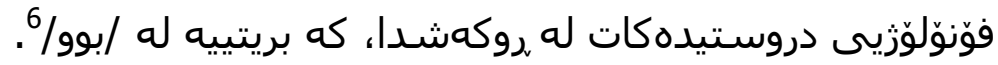
/ - rV

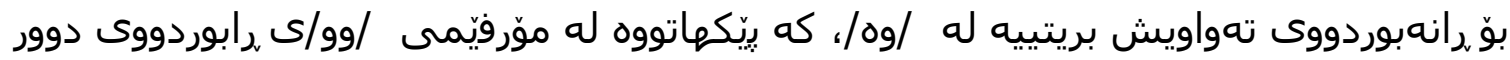

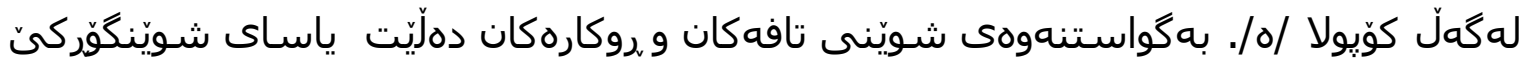
مهبهستى لهم دروستهيه بيتي:

$$
\text { ^r / / انوستووه/ }
$$

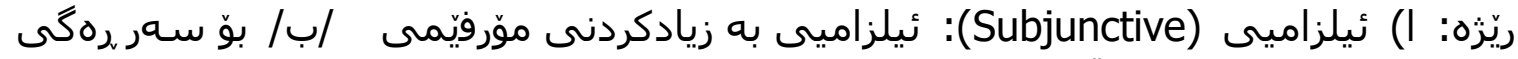

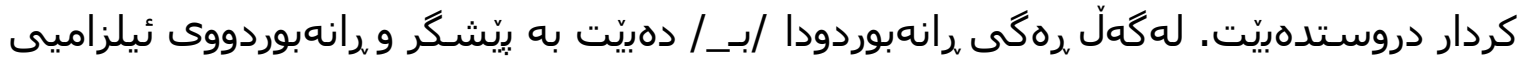

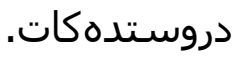

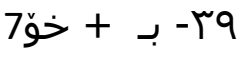

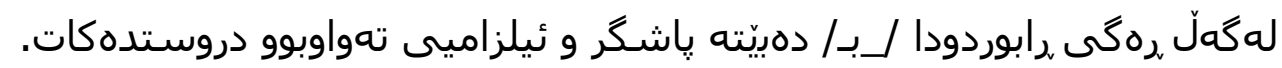

6 - وريا عومهر ئهميين هيج رونكردنهوهى لهسهر بؤوه نهداوه، كه بوّحى به توخميّكى

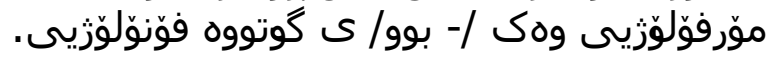

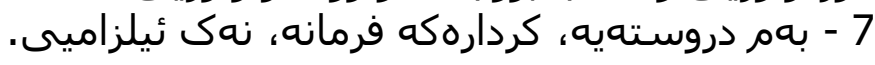




$$
\text { - خ- }
$$

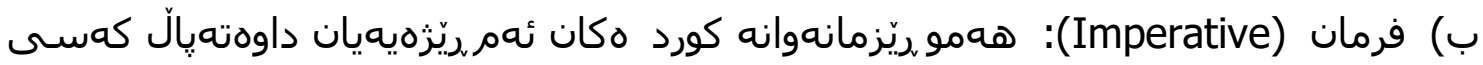

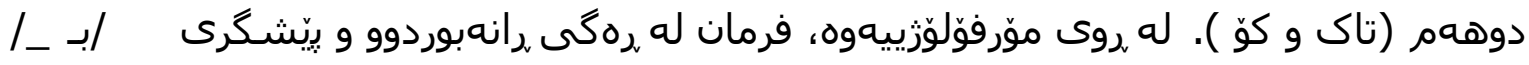

دروستـدهبِيت.

$$
\varnothing+\text { بـ + }
$$

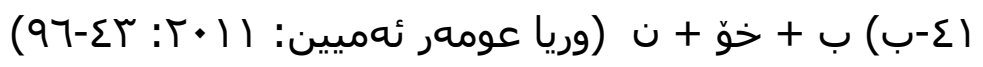

\section{كورتهو يوخته}

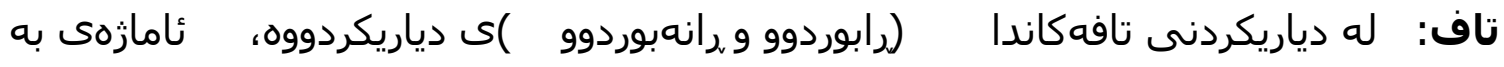

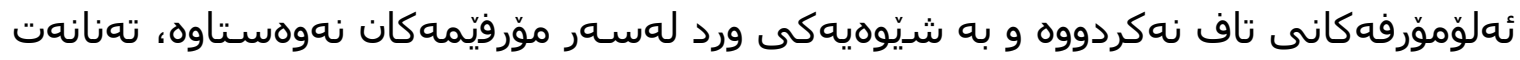

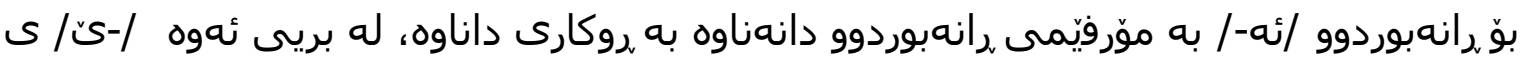

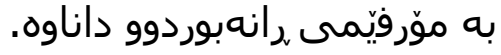

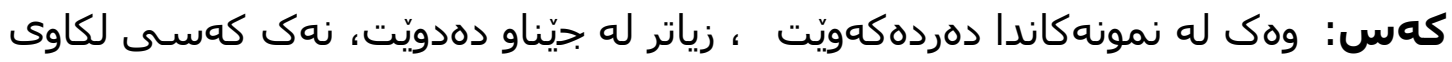

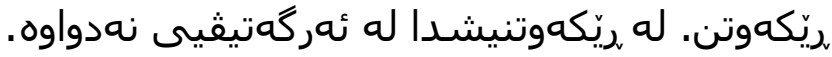

روكار: سـن جوّر روكارى دهستنيشـانكردووه ؛ تهواوبوو، تهواونهبوو، تهواو، كه ئهم

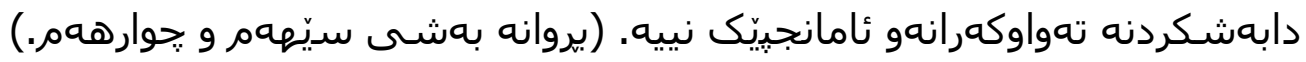
ريّزّه: دوو ريّزْى جياكردونهتهوه؛ (سهبيونتيف و فهرمان) و ئامازهى به هaواليّى نهداوه.

\section{(Y-Y/Y مهحموود فهتحولا}

ئهم زمانهوانه له بِهوهنديى زيّوان ناوى كرداريى و شكانهوه و شكاندنهوهى كردار

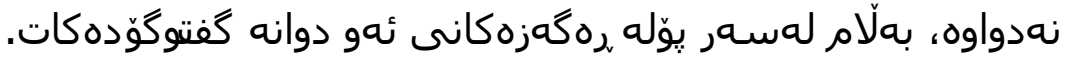

تاف كاتيكوّرييهكى ريّزمانييه، به هوّى موّرفيميّكى دياريكراوهوه دروستدهوريّيت، كه

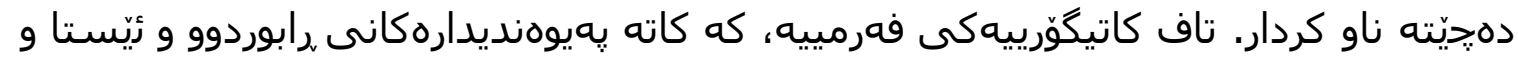

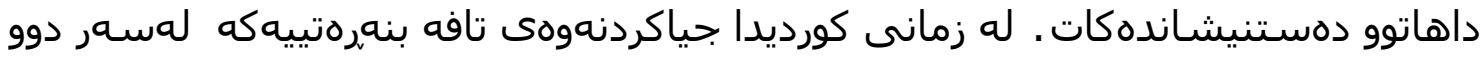

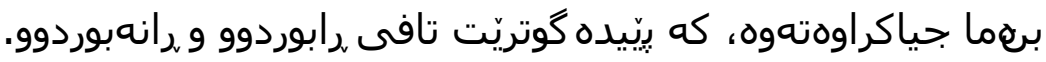

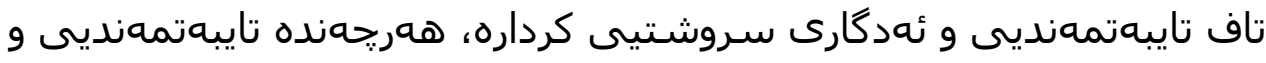

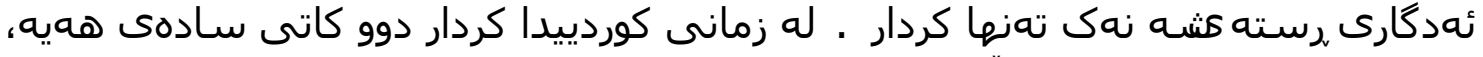

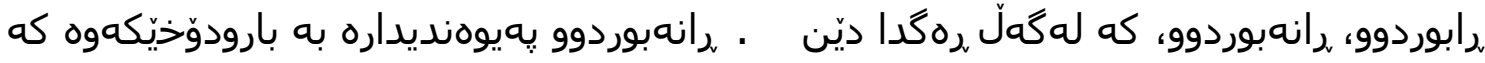

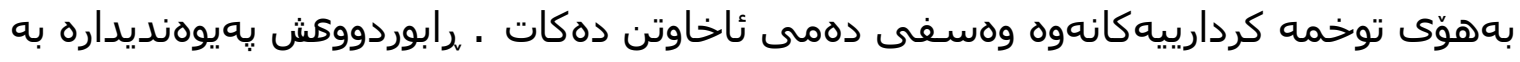

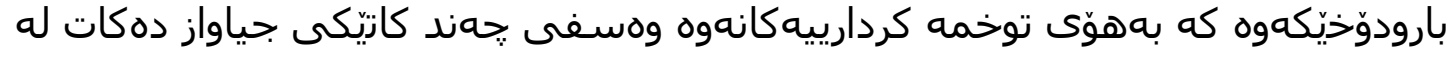
، مرابوردوودا. 


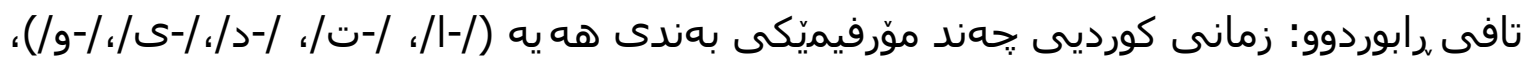

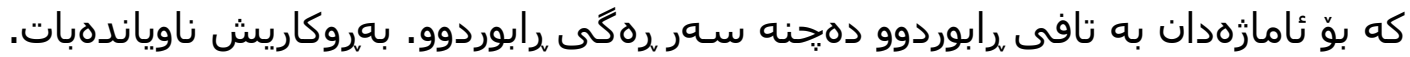

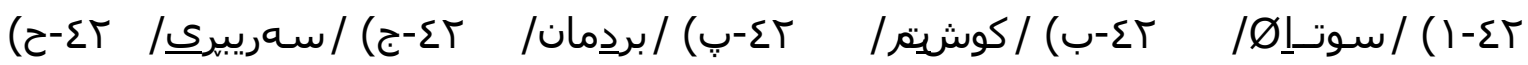
/جوين/

تافى رانهبوردوو: له بِيشـكرى /ده-/، رهذى ،رانهبوردوو و جيّناوى كهسيى دروستدهبيت.

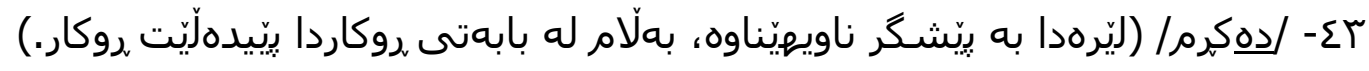

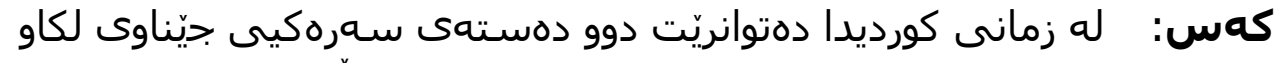

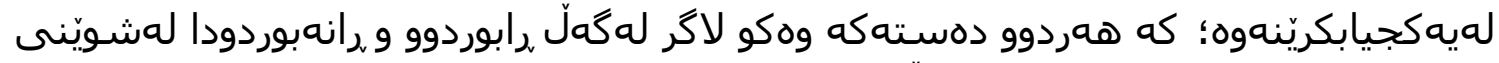

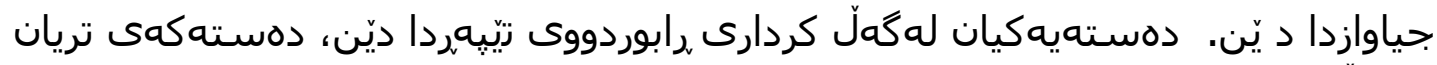

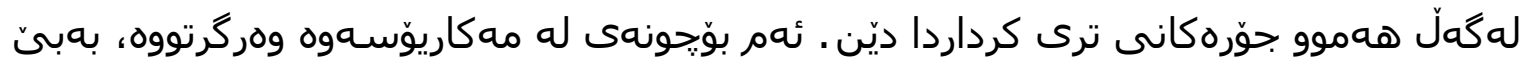
ئهوهى ئامازهييِّبدات.

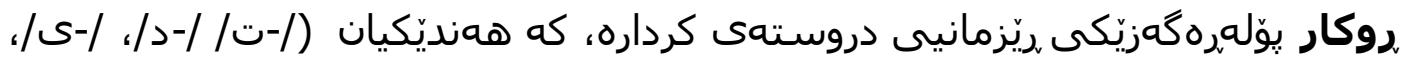

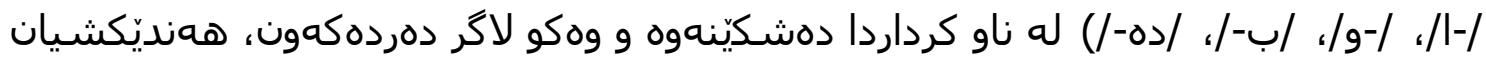

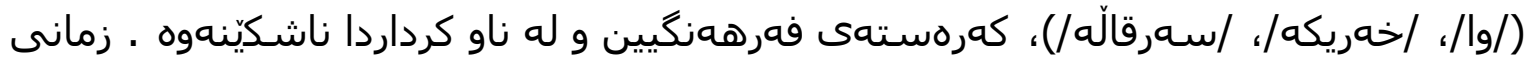
كورديى سـن جوّر ،روكارى ههيه:

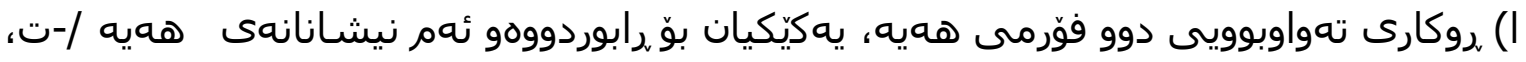

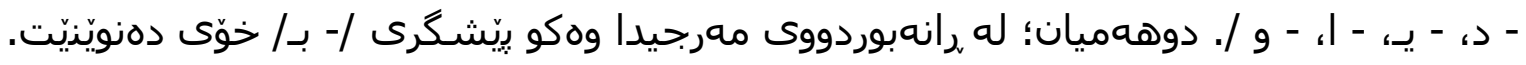

$$
\begin{aligned}
& \text { ع ع- سوت - } \\
& \text { 0ـ- كوش - ت - م } \\
& \text { \ع- بر - د - مان } \\
& \text { EV } \\
& \text { ^ی } \\
& 0 \text { - } 0 \\
& \text { •- }
\end{aligned}
$$

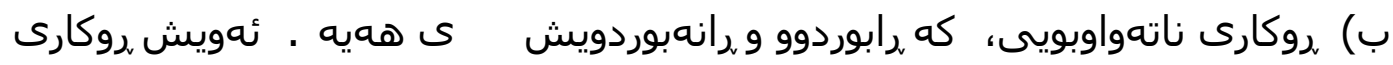

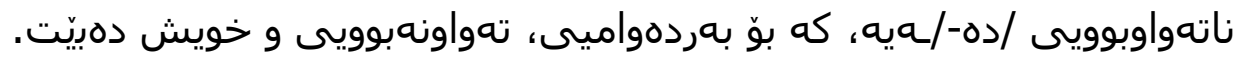

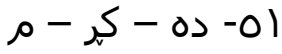

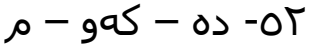

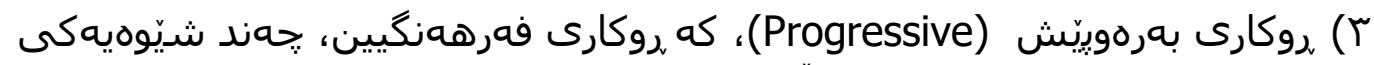
جياجيان هويه، وهى /خهريكه، وا، سـورقالّه، همر/.

International Journal of Kurdish Studies Vol.4/1 (January 2018 ) 


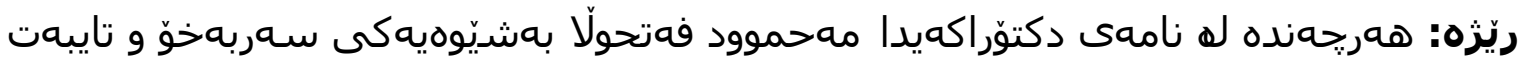

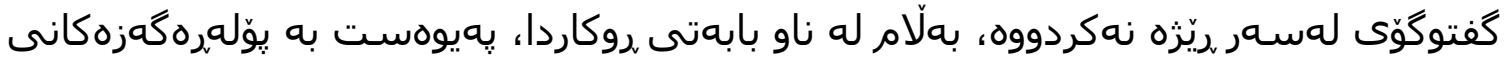

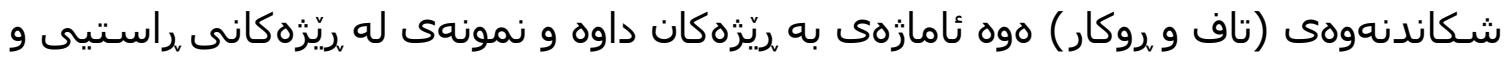

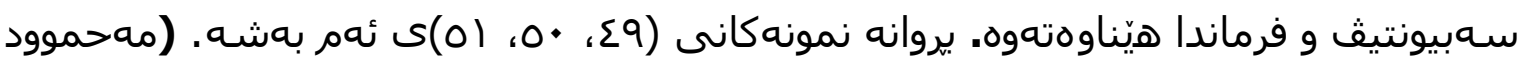

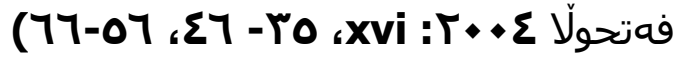

\section{كورته و يوخته}

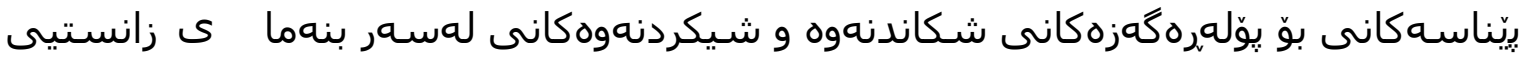

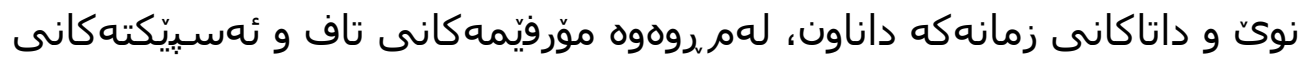

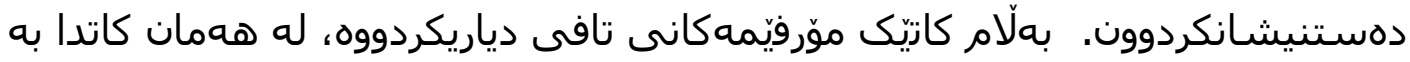

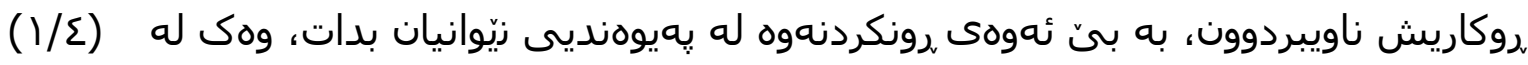

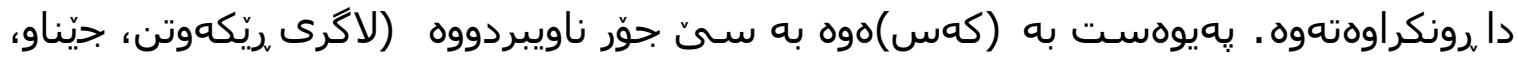

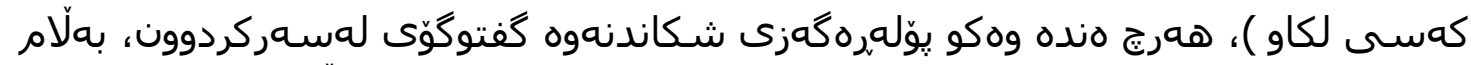

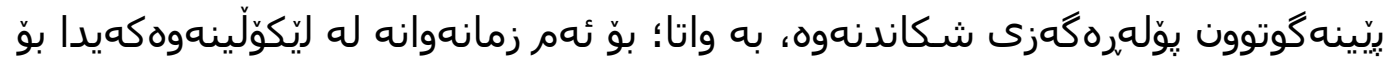

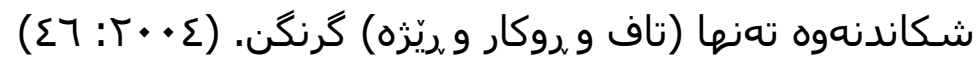

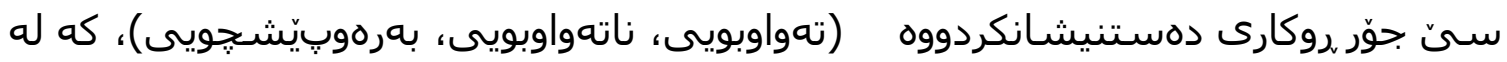

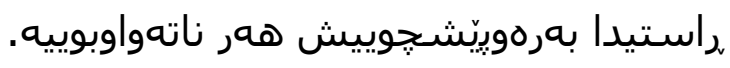

\section{بهى سمهم}

\section{شكاندنهوهى تافى رابوردو9 وردانهبوردووى كردار}

شـاندنهوهى كردار: واتاى نويّمان نييه تا وشهَى بوّ دروستبكهين، وهك له وشهـ

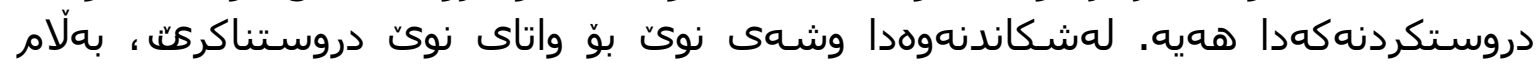

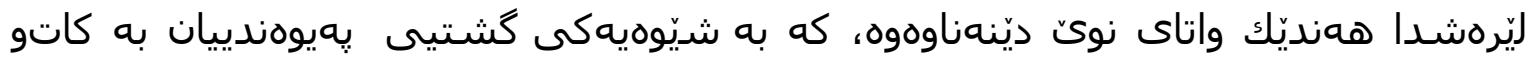

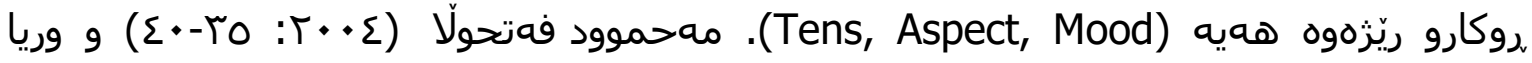

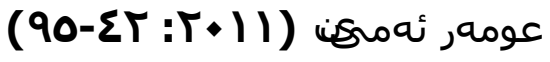

$$
\begin{aligned}
& \text { شـكاندنهوه = كات + كهس } \\
& \text { كهردانكردن = كهس } 8 \\
& \text { تافى بـايوردوو: }
\end{aligned}
$$

شـكاندنهوه بريتييه له هيّنانى قهدى تافيى + گهردانكردن

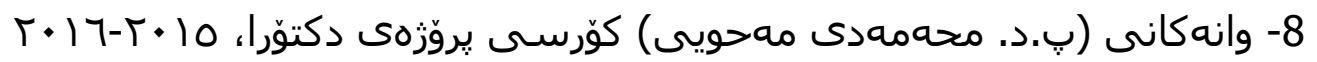




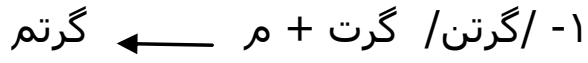

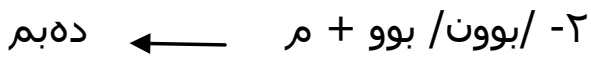

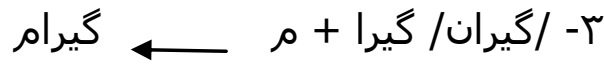

$$
\begin{aligned}
& \text { تافى رانهوردوو: } \\
& \text { شكاندنهوه= هيّنانى تاف + گهردانكردن } \\
& \text { م ש } \longleftarrow \text { ـ } \\
& \text { ـ }
\end{aligned}
$$

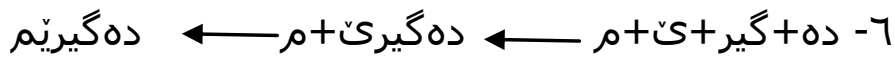

$$
\begin{aligned}
& \text { كهواته گَردانكردن = «الاككردنى تاف }
\end{aligned}
$$

تهنانهت يهكيّك لهتايبهتمهنديهكانى زمانى كوردييه، كه بكهرديارو بكهرناديارى

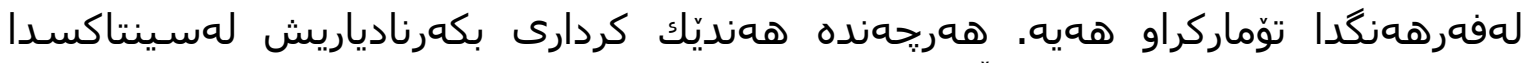
بهرههمدهيَنريّن، وهك /هاتنهوكول/.

لهكرمانجى ناوهراستدا قهد يان رهذى ن ناوه كردارييهكه دههيّنينهناو سينتاكس بوّ ئهودى رسته بهرهم مبعيريكن. خشتهى (ץ-1) لوفهرههنگدا (كوشتن) ناوى كرداريمان هويه

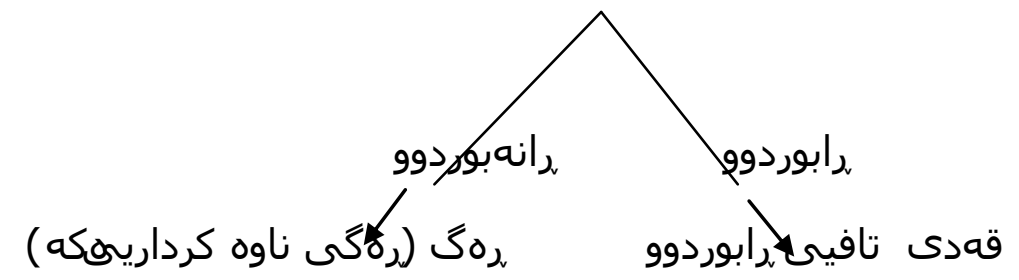

V - (كوشت، كوش) لهكاركوتوونو سـتن، هوتا كاتو كهسى لكاوى بدريتّى.

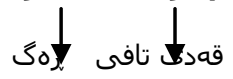

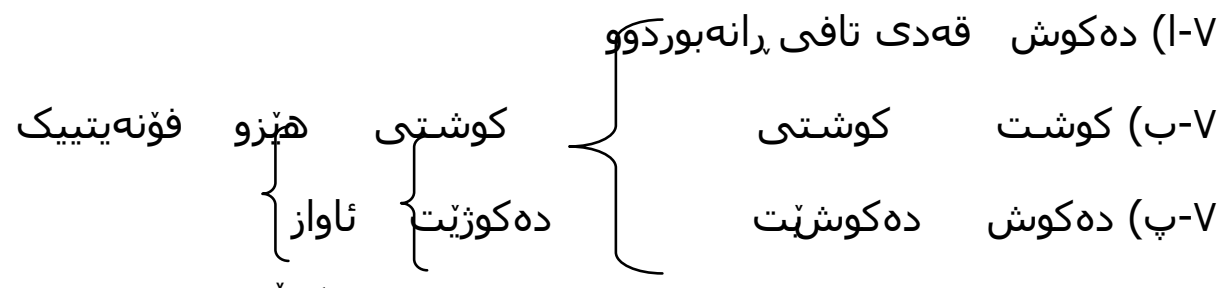

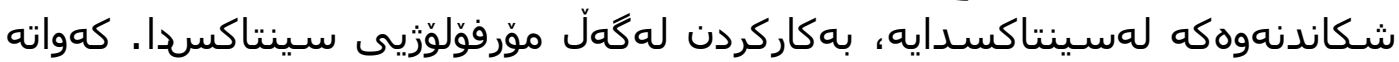

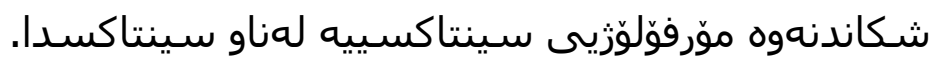
خشتى (T-T) هونكاوهكانى شكاندنهوه 


$$
\begin{aligned}
& \text { يِّيدانى تاف (هونكاوى يهكهمهם) } \\
& \text { بِيْوهلكانى كهسى لكاو (گهردانكردن) (ههنكاوى دوهممه) } \\
& \text { كردارى شكاوه لهدوو شويّندا ههيه فريزّى كرداريى } \\
& \text { موّرفوّسينتاكس }
\end{aligned}
$$

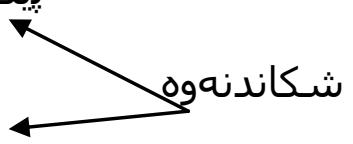

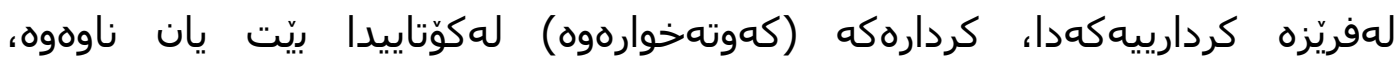

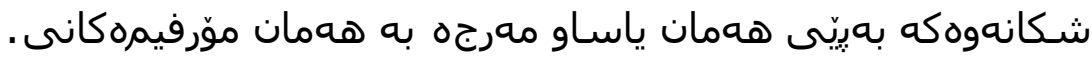

ب/1) شكاندنهوهى كردار به كَردانكردن (لكاندنى كهس و زماره / كليتيكهكانى ريّكهوتن)

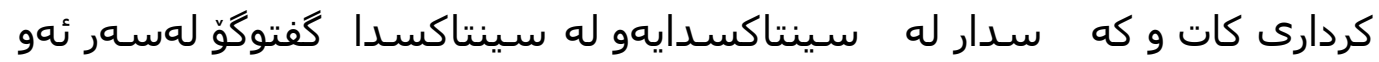

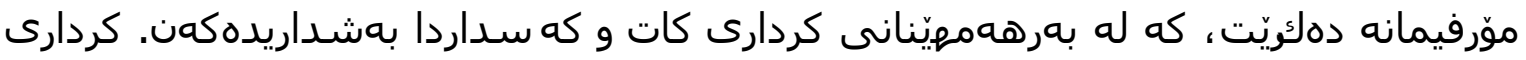

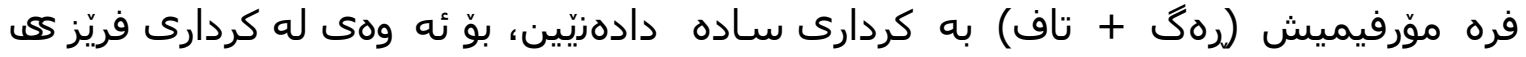

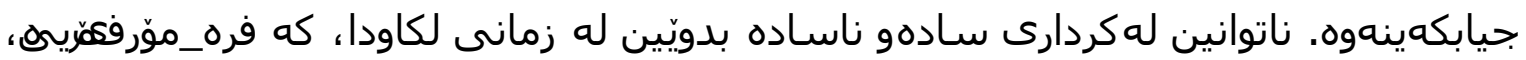

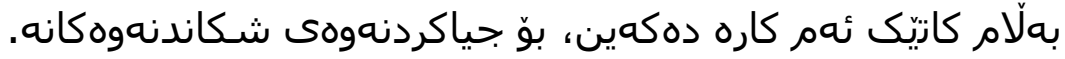

$$
\begin{aligned}
& \text { 1- /گرتم/ شكاندنهوهى كردارى سادهيه. } \\
& \text { 9- /سهرهمكرت/ شكاندنهوهى كردارى ليّكدراوه. }
\end{aligned}
$$

• ا - /دهستى بهسـر شارهكها كُرت/ شكاندنهوهى كردارى فريزيه. ناوه كردارييهكهش له ناو فهرههنكدا ساده، هـلّكويّزراو و ليّكدراوى ههيه:

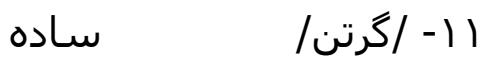

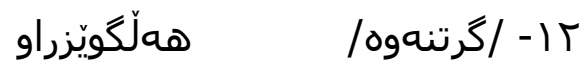

$$
\begin{aligned}
& \text { با - /سهرهكرتن/ ليّكدراو }
\end{aligned}
$$

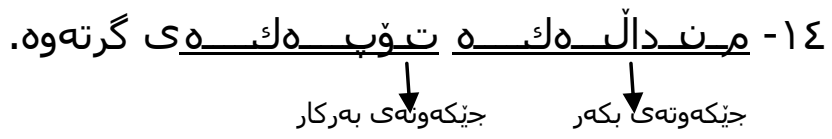

شكاندنهوهكه بريتييه لوهى، كه كهسى بِيْوه دهلكينريّت:

$$
0
$$




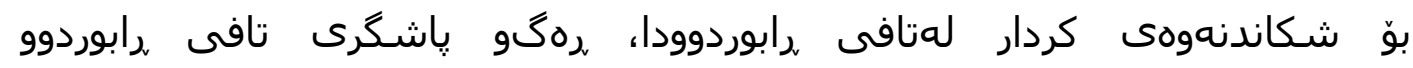

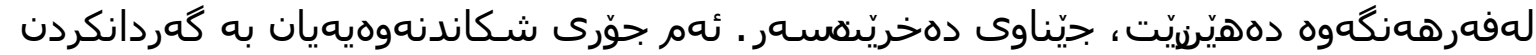

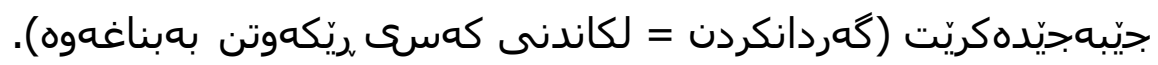
تيبينيى: قهد بوّ وشهدروستكردنه: 7 ا - كوردِ يّتى قa

بناغه بوّ شكاندنهوه بهكاردى: V I - گرتِ + ى بناغه

كaوl ا - بهم رِيِيه بوّ شـكاندنهوهى ،رابوردوو، بناغهى تافيى للفهرههنكهوه دههينريّت.

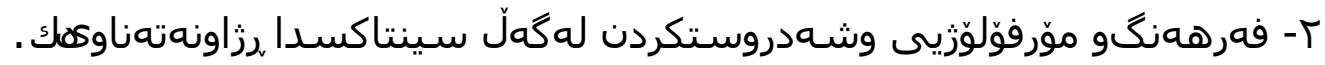

\section{Y/Y) شكاندنهوهى كردار به كَهردانكردن و لكاندنى كaسى ريّككهوتن}

بناغهى تافى ،رابوردوو لهفهرههنگدايه لهناو ناوه كردارييهكهدا (گرت). بناغهى تافى

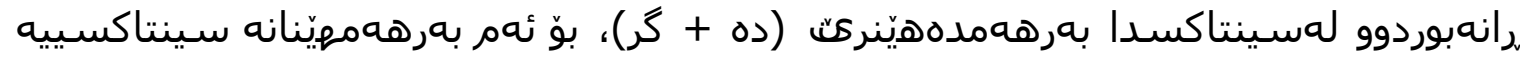

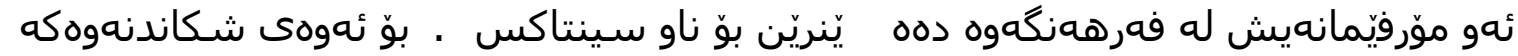

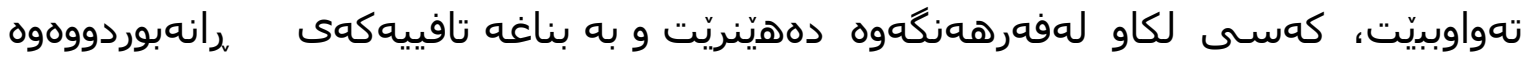

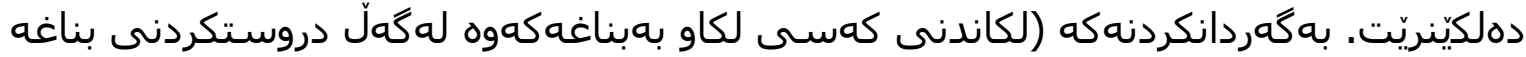

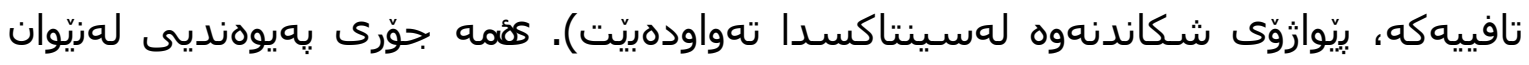

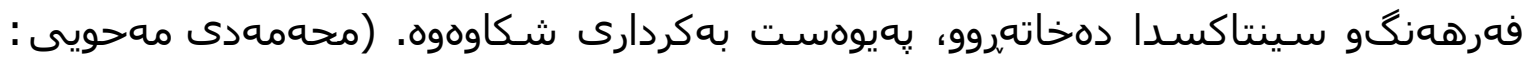
(r)

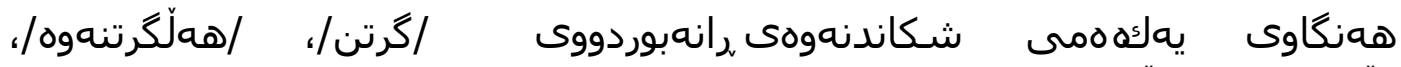

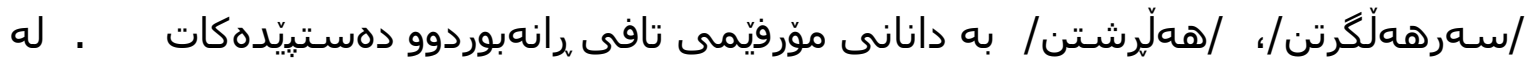

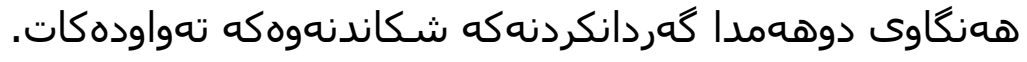

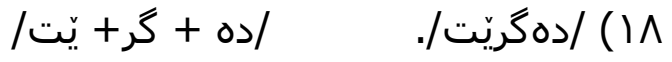

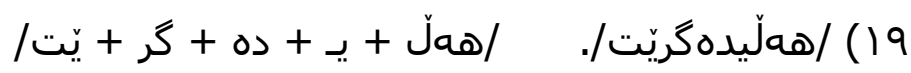

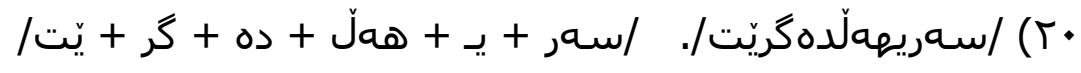

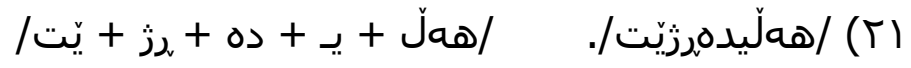

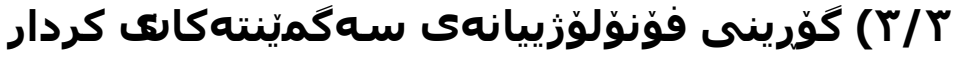

International Journal of Kurdish Studies Vol.4/1 ( January 2018 ) 


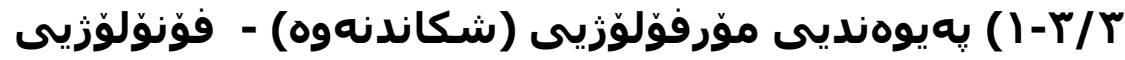

دوو جوّر / /بوون/ جياكراونهتهوه، كه /بوون/ى كردهيى و /بوون/ى حالّهتيين ـ (يروانه

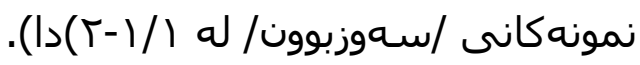

$$
\text { זٓ-ا) باميّكه زهرد بو. (حالّهتيى) }
$$

זٓب) باميّكه زهردبوو. (كردهيى)

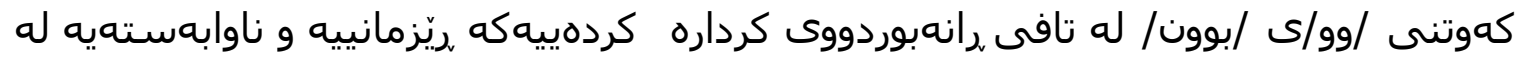

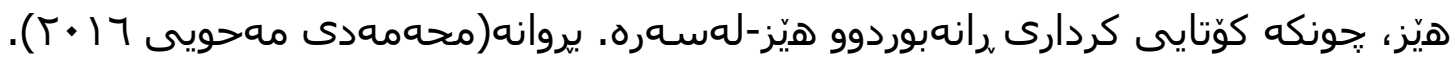

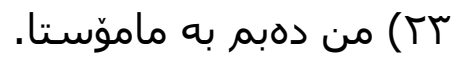

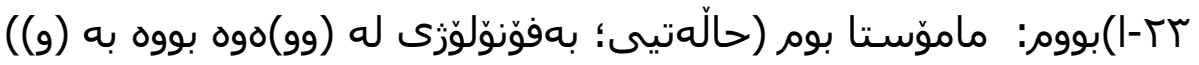

$$
\begin{aligned}
& \text { זٓ-ب) بووم به ماموّستا. (كردهيى) } \\
& \text { ץץ-ب)دهبم: ماموّستايه (كرداربهنديى) }
\end{aligned}
$$

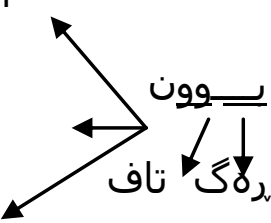
ب م ناياسابهندهو رونكردنهوهى نييه

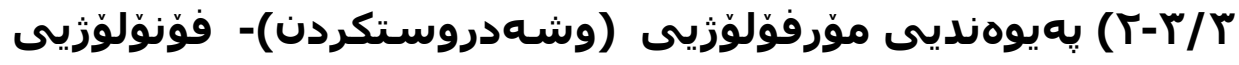

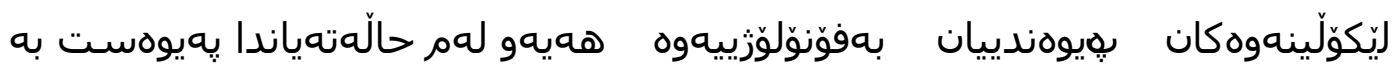
موَرفوّلوَزَييهوهن.

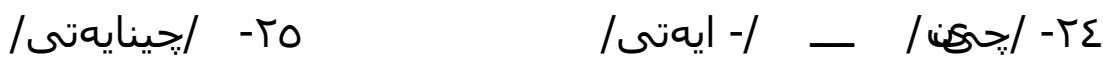

$$
\begin{aligned}
& \text { [ t } \left.\left.\int \mathrm{i} \cdot \mathrm{na} \cdot y ə \cdot \mathrm{ti}:\right] \quad \text { [a. yə. ti: }\right]-\left[\mathrm{t} \int \mathrm{i}: \mathrm{n}\right]
\end{aligned}
$$

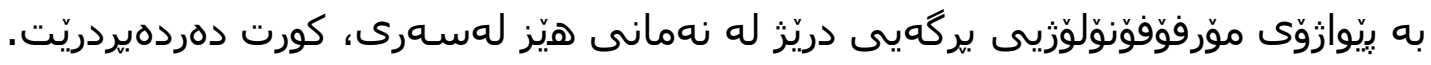<smiles>[AsH2]=[WH]</smiles>

له ناوهندى دهنكدارييشدا، خشوّكه كيهكان دهبن به دهنكدار:

$$
\text { Tr- /كوشتن - مر/ }
$$

$$
\text { [ku.3ər] } \sim\left[\mathrm{ku} \int \mathrm{tin}\right]
$$

لهم حالّهتهياندا خشوّكيّكى [ - دهنكدار ] دهيّت به خشوّكيكى [ +دهنكدار ]. 


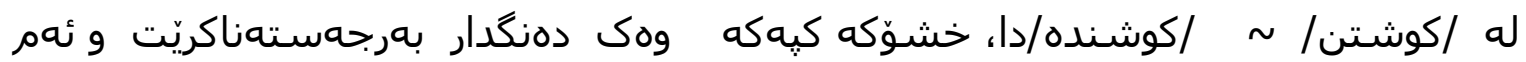

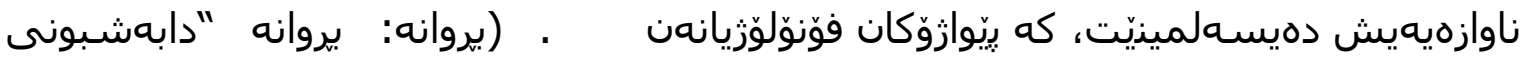

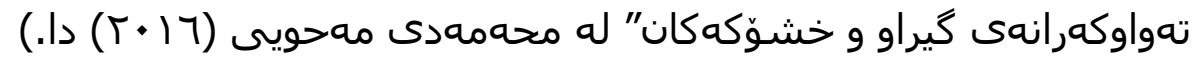

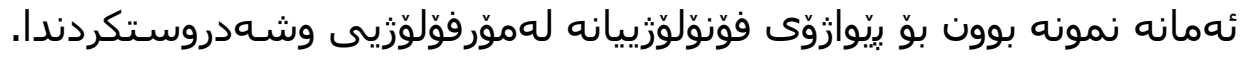

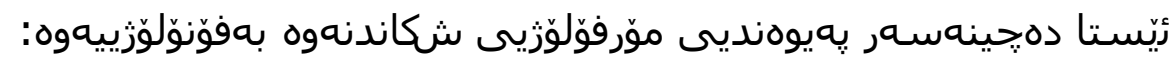

$$
\text { درستهى رابوردوو رب رانهبوردوو كوشت }
$$

دهوروبهره دهنكدارككه له شكاندنهوهى تافى رانهبوردويشدا ههر مهرجى به دهنكدار بونى

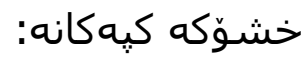

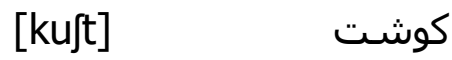

$$
\begin{aligned}
& \text { [də . ku .3e:t] ] د }
\end{aligned}
$$

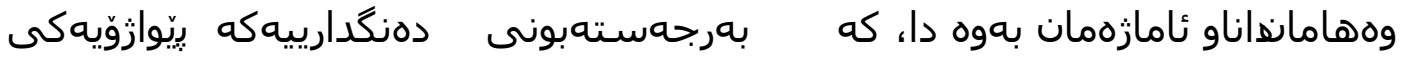

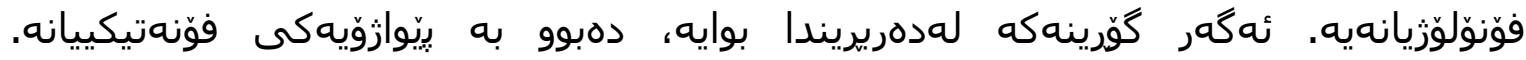

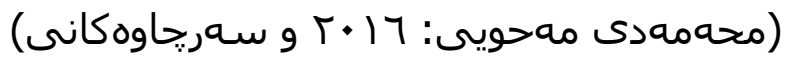

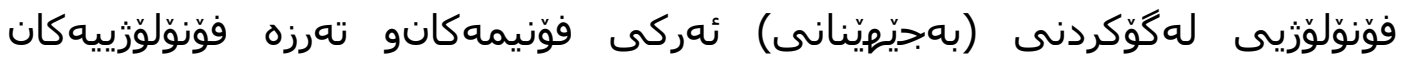

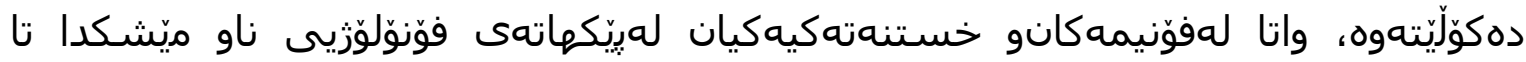

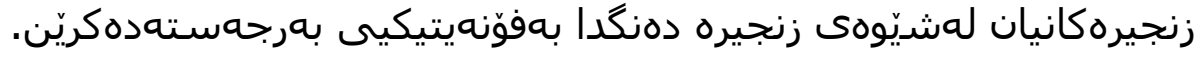

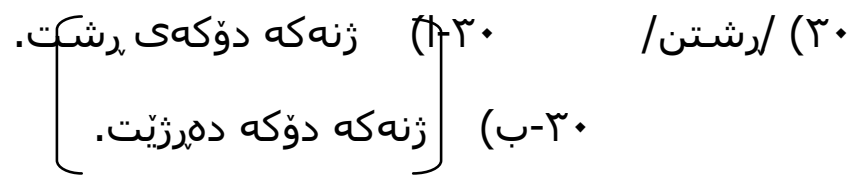

ناوازهكان ئامازهن بوّ ئهوهى، كه دهبيت كُورينى دهنكدارى وشهدروستكردن و

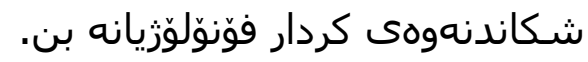

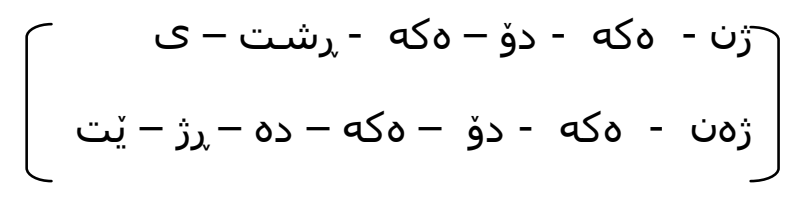

\section{بهشى جوارهم}




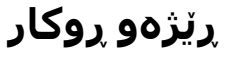

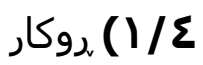

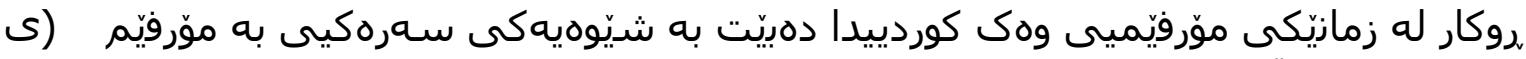

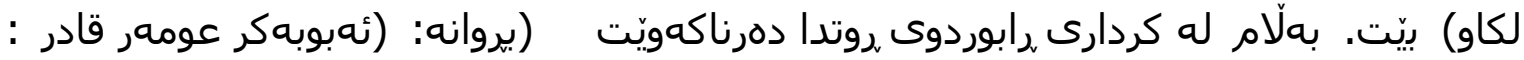

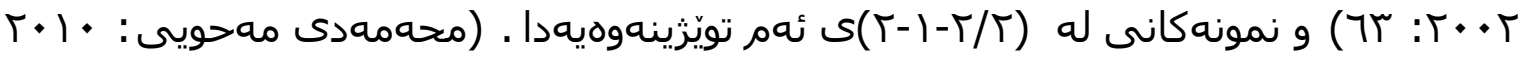

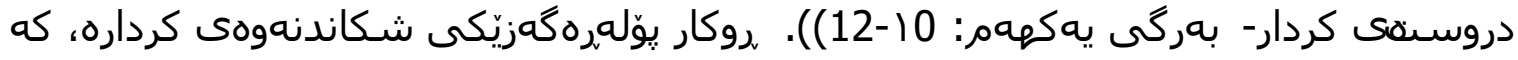

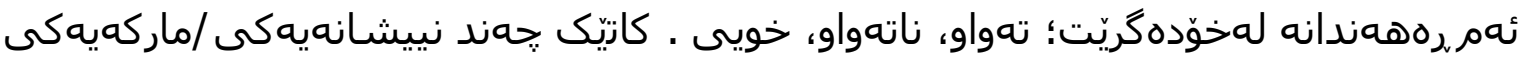

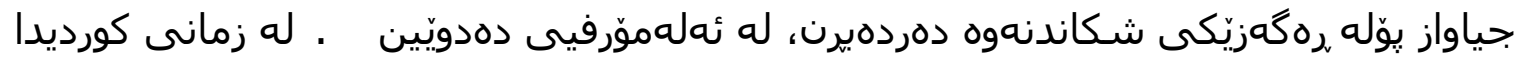

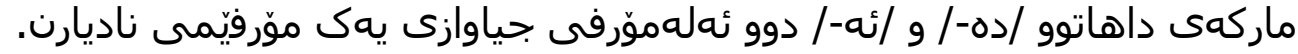

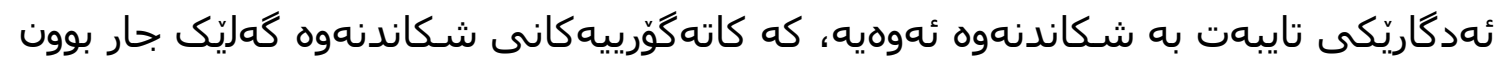
به شاكرووي و ئهمهيش ناونراوه

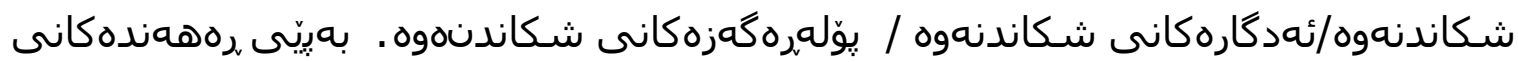

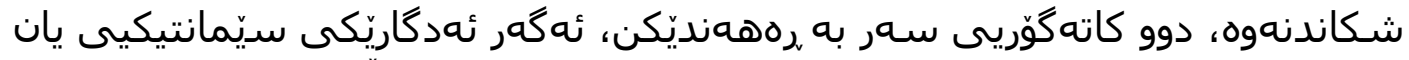

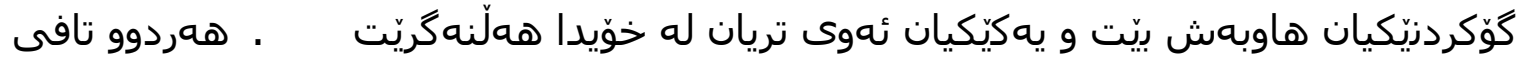

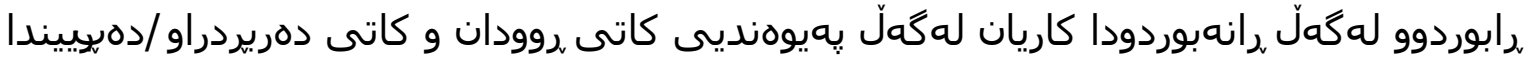

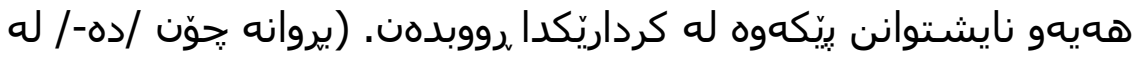

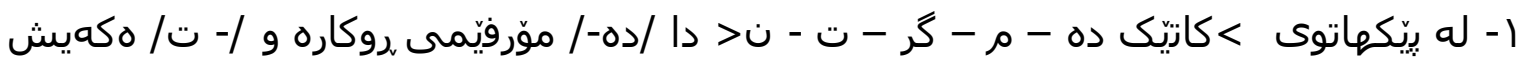

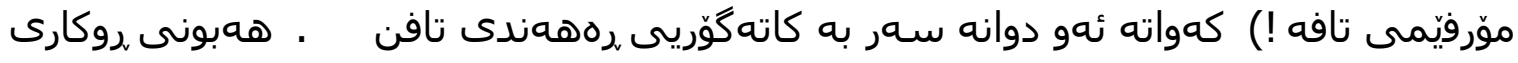

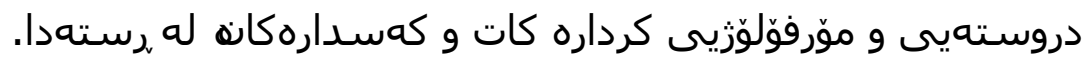

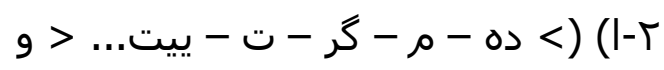

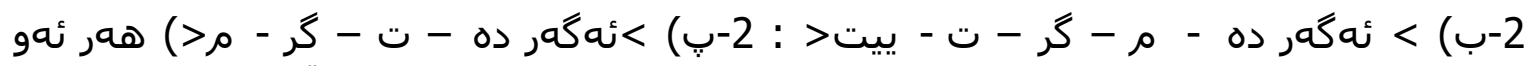

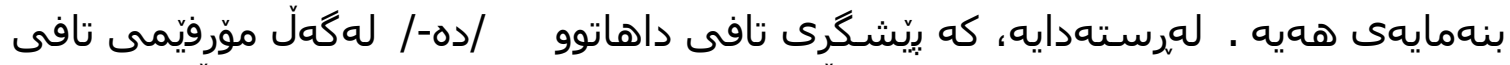

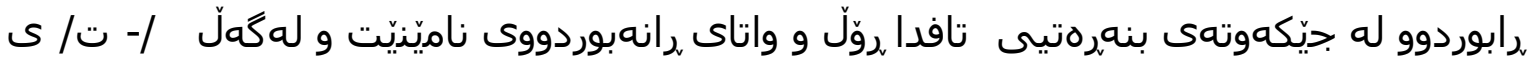

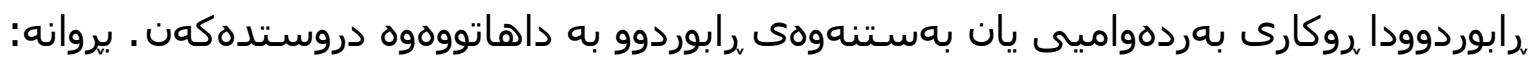

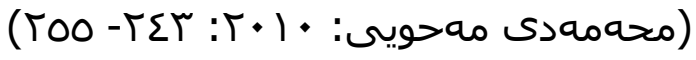

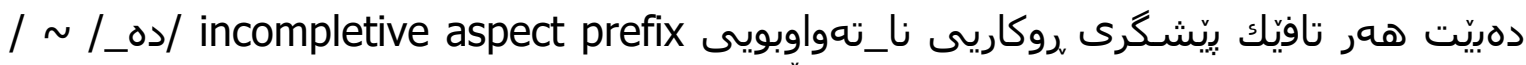

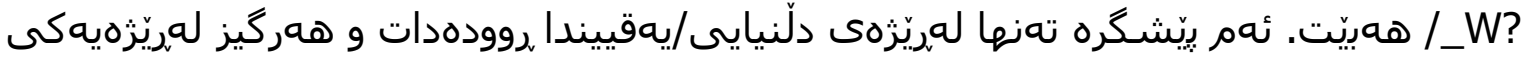

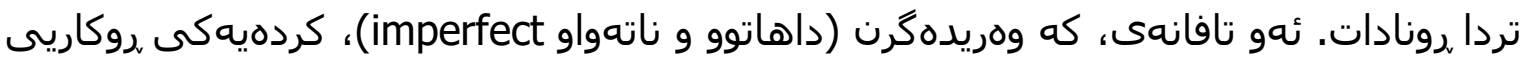

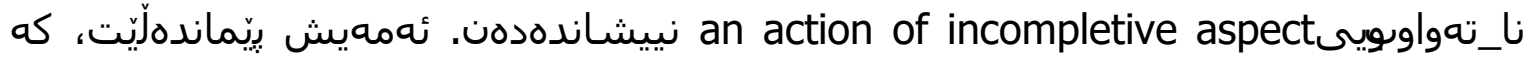

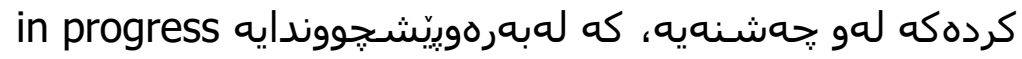

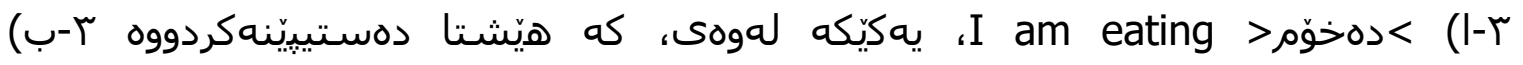
> عادخومر > I will eat, or I am going to eat

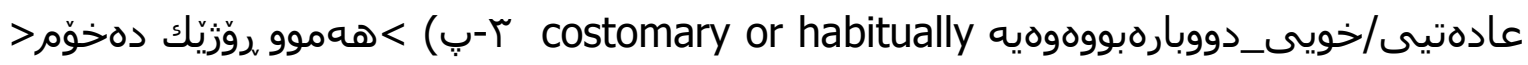
I eat every day

International Journal of Kurdish Studies Vol.4/1 ( January 2018) 
كردهى تهواوبوو completed action نييشاندهدهن، وهك رابوردووى ساكار. لهبهرئهوهى ههر

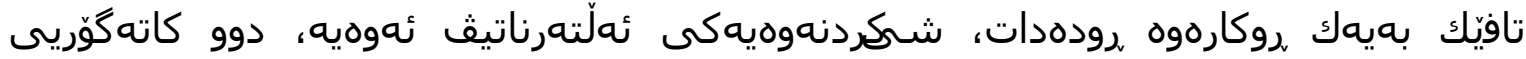

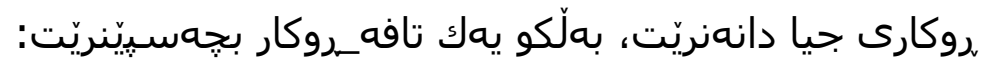

incompletive present completive preterite incompletive-imperfect completive present perfect completiv- past perfect

$$
\text { بaرگ (I) }
$$

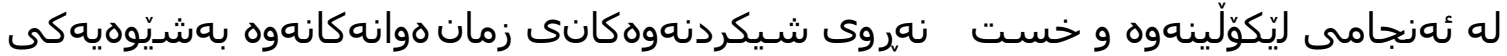

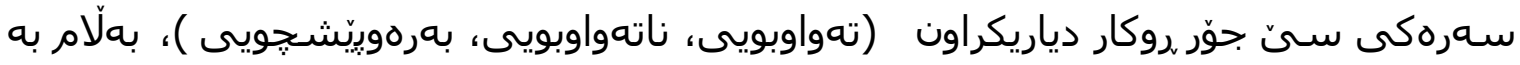

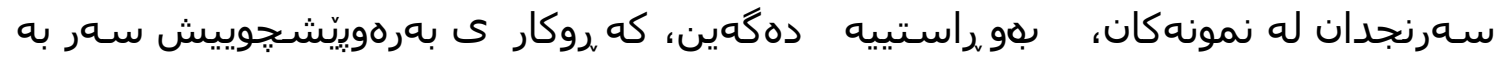

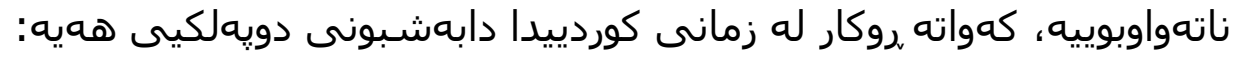
دروكار

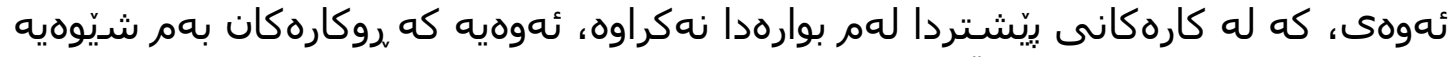

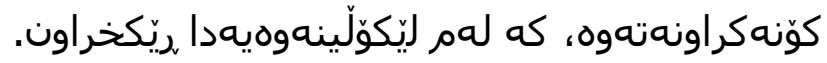
ناتهواوبويى ع- نُهو ماموّستا بوو. (ئيسـتا ماموّستا نييه) 0- ئهو نوستبوو، كه ئولة كهيشـن. (ناتهواوبويى دوور) به برگهيى دريّزيش دهكريّت. يروانه (محهمددى مهحويى: 7 • • )

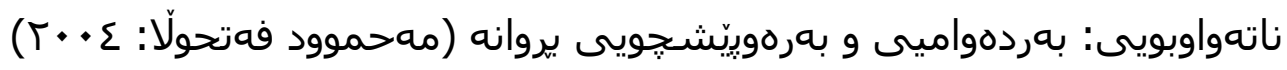

\section{(T/}

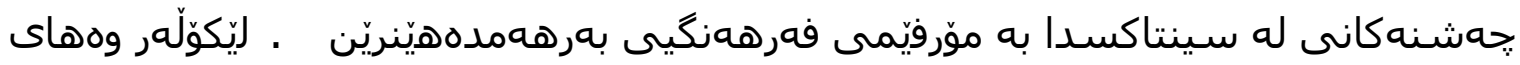

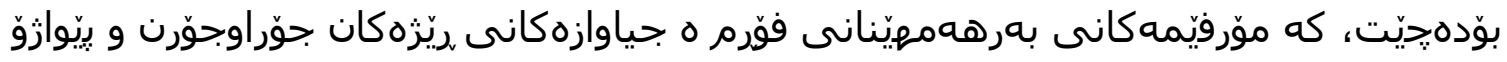

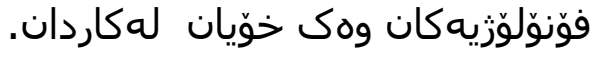

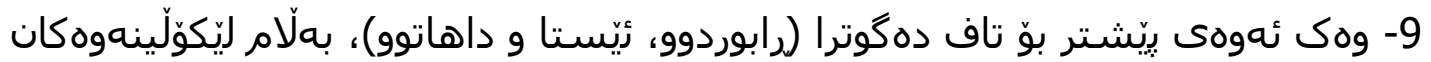

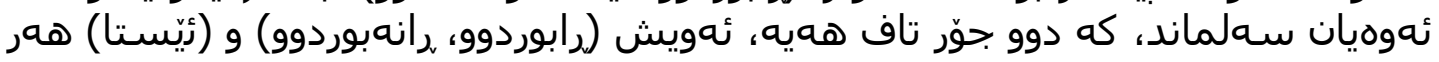
بهشيّكه له لمرانهبوردوو.

International Journal of Kurdish Studies Vol.4/1 ( January 2018) 


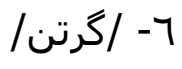

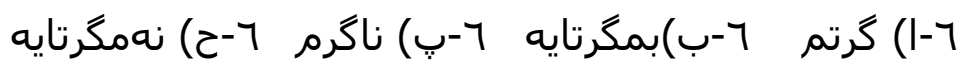
ريّرَهيش به هومان شديّونى روكار دابهشبونى دويهلكيى ههيه:

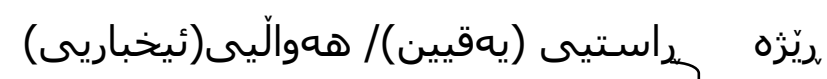
كومان / ئينشائيى، دانانيى، فهرمان، داخوازيى....

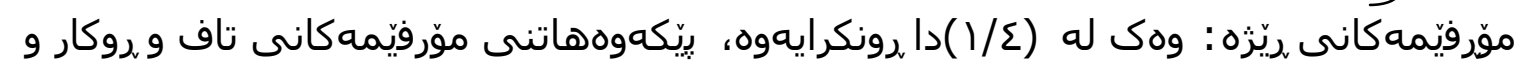

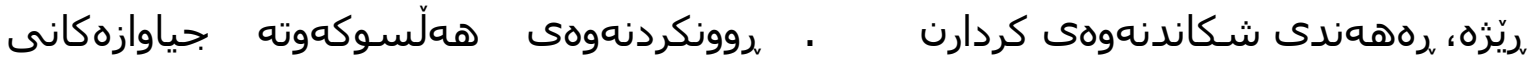

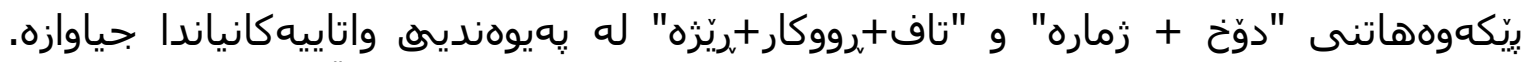

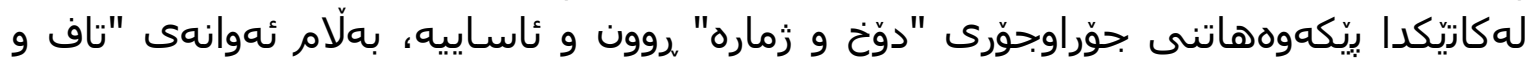

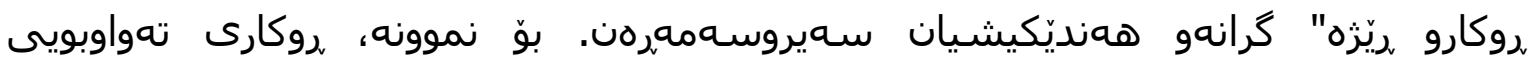
ني perfective aspect

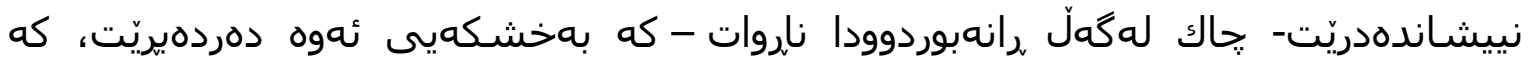

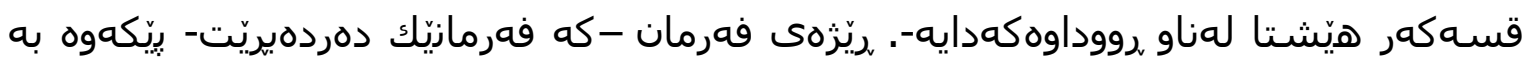

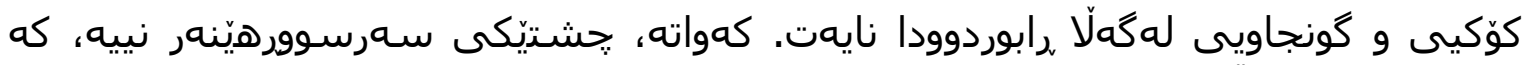

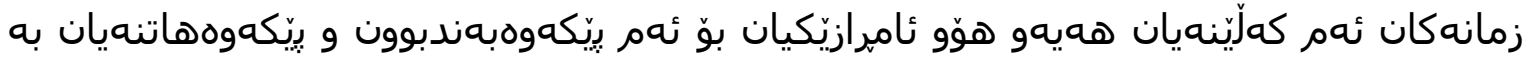

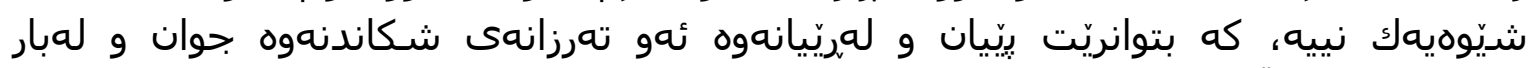

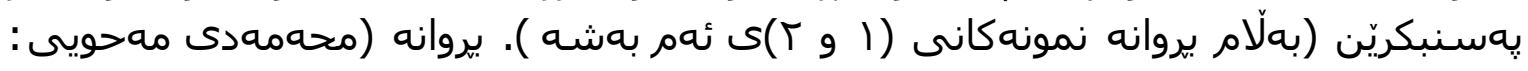

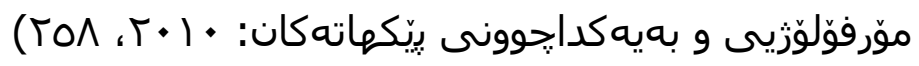

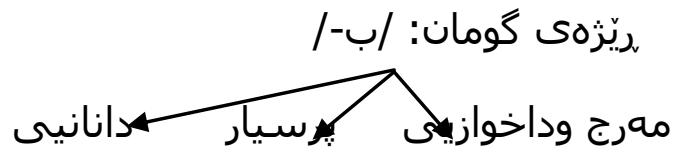

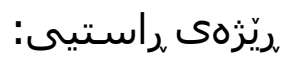
هووالّيى_دهربير

\section{|ئهنجام}

ا - ناوى كرداريى له فهرههنكدا توّماركراوهو بِيّوازوّى شكاندنهوهى له سينتاكسدا رودهدات. ז- لكودارى كات و كهسدار له سينتاكسـا بهرههمدههينريَت، نهى له موّرفولّوَّيدا.

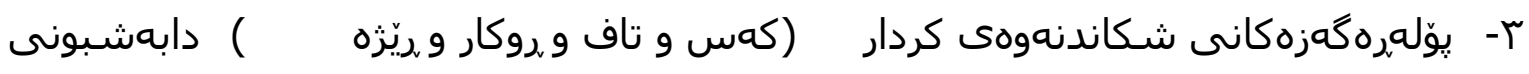

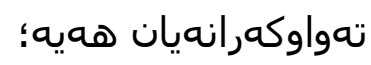

$$
\text { كمس: تاك، كوّ }
$$

تاف: رابوردوو، ،رانهبوردوو

دروكار: تهواوبويى، تهواونهبويى 
ريّزَه: راستيى، گُومان (ئينشائيى، دانانيى، فهرمان، داخوازيى....

\section{سaريحاوكان}

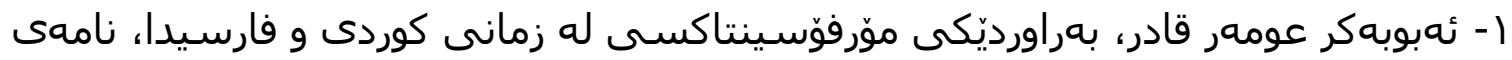

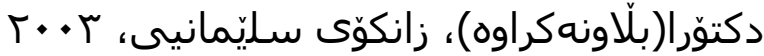

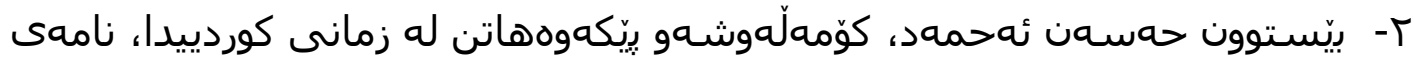

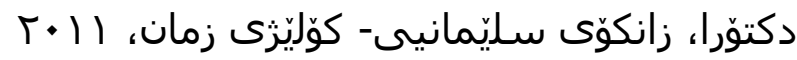

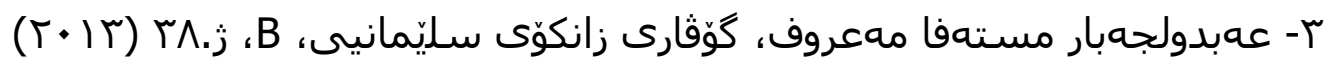
ع- محهمهدى مهحويى، بنهماكانى سينتاكسى كورديى، بهرگى يهكهم، زانكوّى

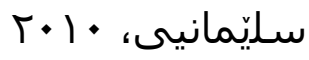

0- محهمaدى مهحويى، شكانهوهى كردار،زانكوّى سليّمانيى، • ( • 7- محهمهدى مهحويى، كاروان عومهر قادر، شييلان عومهر حسيّن. دروستهى كردار،

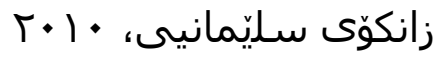

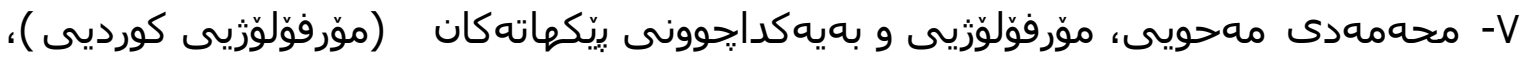

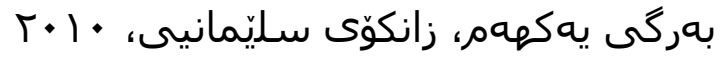

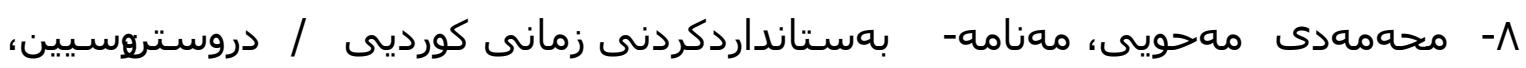

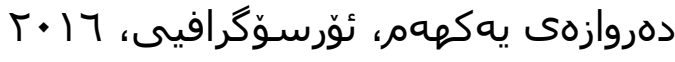

9- محهمهد مهعروف فهتاح، كاريوّلينكردن بهيِيى روّنان، روّشنبيرى نوكّ، زماره (121)، (1989)

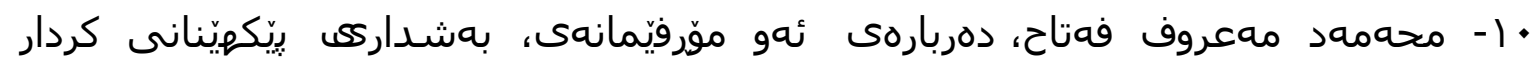

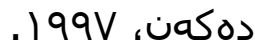

11- ASPECTS OF THE VERBAL CONSTRUCTION IN KURDISH, WARIA OMAR AMIN, LONDON UNIVERSITY, HAJI HASHM PRINTING HOUSE, 2011.

12- The Tense and Aspect system in Kurdish, Mahmoud Fathulla Ahmad, A Thesis Submitted for the Degree of Doctor of Philosophy at The School of Oriental and African Studies, University of London. Linguistic Department. 2004. 